\title{
Evaluation of the Final Report: Waste Package Materials Performance Peer Review Panel
}

Prepared by:

Jack N. Bailey, Jack D. Cloud, Thomas E. Rodgers, and Tammy S.E. Summers

Prepared for:

U.S. Department of Energy

Yucca Mountain Site Characterization Office

P.O. Box 364629

North Las Vegas, Nevada 89036-8629

Prepared by:

Bechtel SAIC Company, LLC

1180 Town Center Drive

Las Vegas, Nevada 89144

Under Contract Number

DE-AC28-01RW12101 
used to evaluate the effect of potential heat-to-heat variability of corrosion properties and alloy phase stability. If necessary, the chemistry ranges can be narrowed to minimize metallurgical changes while maintaining satisfactory mechanical and corrosion properties. See also the responses to Comments 2-11 and 3-24.

\subsection{RADIATION EFFECTS}

Comment 3-27 (page 28; see also pp. 61, 63, and 86): The panel recommends that the Project complete the following analysis: 1) perform a calculation of the $\mathrm{H}_{2} \mathrm{O}_{2}$ concentration expected in the repository water, 2) measure the open circuit potential at the repository relevant $\mathrm{H}_{2} \mathrm{O}_{2}$ concentration, 3) directly measure the shift in the open circuit potential of alloy 22 in the presence of gamma irradiation, 4) assess the stability of the open circuit potential as a function of time for Alloy 22 exposed to gamma irradiation. Radiolysis measurements should be conducted using repository relevant waters in an autoclave system that allows continuous measurement of the open circuit potential to be made up to $170^{\circ} \mathrm{C}$. High temperature measurements are desirable because of the need to measure film stability and because this stability is temperature dependent. It would be desirable to measure the current-voltage response of the material in the gamma flux but this is of a lesser priority then measuring the stability of the open circuit potential as a function of time. It would also be desirable to measure the film chemistry following long-term exposure to the ionizing gamma irradiation field, but this is a lower priority because of the complexity of measuring film chemistry when samples are transported through air. Available gamma sources generally produce at least a factor of 100 times higher flux than that expected in the repository. Therefore, tasks numbered 1 and 2 are needed to provide specific data on open circuit potential shifts at repository relevant conditions. The current-voltage curves should be determined as a function of $\mathrm{H}_{2} \mathrm{O}_{2}$ concentration at repository relevant temperatures.

Response: The Project has concluded that the effects of radiation on the corrosion rates are of low priority based on Project experiments and the available literature. The expected radiation levels on the surface of the waste package containing the "hottest" fuel is estimated to be too low (less than $50 \mathrm{R} / \mathrm{h}$ ) to have any important effects on the corrosion potential. The effects of radiation on solution chemistry have been evaluated and screened out. See also the response to Comment 2-19.

\subsection{ENNOBLEMENT}

Comment 3-28 (page 29; see also p. 85): The Panel recommends that the electrochemical measurements on samples exposed in the Long Term Corrosion Test Facility continue, as should measurements on fresh samples in old solution and on aged samples in fresh solution. These experiments will provide improved understanding of the ennoblement process.

Response: These electrochemical measurements are continuing. They include fresh samples in old and new solution and aged samples in old solution. This information will assist in understanding the ennoblement process that the Project has noted for Alloy 22. See also the responses to Comments 2-20 and 7-5. 


\section{COMPOSITION OF AQUEOUS ENVIRONMENTS}

Comment 5-1 (page 46): Due to their location, the ground control structures will be exposed to seepage water well before the drip shield or waste package. The steel sets and rock bolts will likely see the most seepage water as they will not be substantially protected by capillarity effects on flow. In fact, any capillarity effects will lead to seepage water running down the walls of the drift, likely along the steel sets. Note that these structures are expected to last up to 300 years during the monitoring phase. Although outside the scope of this Panel review, the Panel recommends that some corrosion studies be carried out on these materials to determine the corrosion rates that can be expected. In addition, these studies would provide important information concerning the release and transport of ferrous ion by the steel structures. The ferrous ions will quickly be converted to ferric ions by the oxidizing environment within the drift. The extent to which these ferric ions are then transported from the steel sets or rock bolts to the drip shield or waste package by the seepage water could be important. The availability of the ferric ion as an oxidizing species on the drip shield and waste package may impact the likelihood of localized corrosion of these materials. Under the near-neutral or alkaline pH conditions expected in the concentrated brines, the ferric ion will precipitate and not be an effective oxidizer. Under acidic conditions within active localized corrosion sites, however, the ferric ion would not only serve to accelerate the corrosion, but also to provide a source of protons to maintain a low pH. Finally, the steel provides a substrate on which certain microbes may colonize, as discussed in more detail below in Section 5.3.

Response: The effect of corrosion products from ground support (mild steel and concrete) on the evolution of in-drift environment is being modeled as part of in-drift chemistry modeling. This activity uses corrosion rates for the ground support materials from prior analyses conducted by the Project. The effects of modified chemistry from the ground support corrosion on the corrosion behavior of the waste package materials is being investigated with water drip testing under elevated temperatures and constant relative humidity. Tests will be performed where water drips on the ground support material and then on the waste package material. This will allow corrosion testing under transient conditions. See also response to Comment 3-12. 


\section{MATERIALS: METALLURGICAL STABLITY}

\subsection{GRAIN GROWTH}

Comment 6-1 (page 73): The Project currently has no effort to evaluate the grain size as a function of temperature and time. The mechanical properties of a material are a function of the grain size, such as the well known Hall-Petch relationship, between grain size and yield strength. The Panel recommends that alloys available from Haynes be used to develop a relationship between grain size and time and temperature.

Response: Stainless steel, a structurally strong material, was chosen for the inner layer of the waste package to support the corrosion-resistant outer material (Alloy 22). The Project is not relying on the outer material for strength. Although no quantitative measurements have been made on grain size as a function of time and temperature, many aged samples have been examined, and no gross changes in grain size have been observed. Initially, the grain size of solution-annealed Alloy 22 is rather large (on the order of $100 \mu$ ), and no significant effect of grain coarsening is expected under the thermal profile predicted for the repository. In any case, grain coarsening will primarily affect the strength of the alloy, and because Alloy 22 is not used for strength, this work is considered to be low priority.

\subsection{ALLOY SPECIFICATION}

Comment 6-2 (page 73): The Panel recommends that a program heat of material with desired levels of elements within the alloy specification be procured. This must be a sufficiently large heat of material to allow it to be included in all aspects of the program. This is recommended since the current measurements are being made on a variety of heats of material. If there are heat-to-heat variations, the current program results may not correctly predict the behavior for any random heat of material.

Response: Although different project studies are sometimes performed on different heats of material, the samples procured for each individual study are generally obtained from one heat of material. Thus, the conclusions drawn from each study are not complicated from heat-to-heat variability. In addition, heat-to-heat variability studies are planned. The results of these studies and analysis of the heat compositions used in the test program to date will be used to assess the likelihood of heat-to-heat complications in model predictions. The Panel recommendation will be considered pending the results of these investigations. 


\section{LONG-TERM UNIFORM CORROSION OF PASSIVE METALS}

\subsection{STRUCTURE AND COMPOSITION OF THE PASSIVE FILMS AND OXIDE FILMS OF ALLOY 22}

Comment 7-1 (page 84): In general, the Panel recommends better coordination of the generally excellent work underway and planned at UWO [University of Western Ontario], LLNL and GECRD [General Electric Corporate Research and Development Center]. ... The Panel recommends the Project carefully coordinate the analytical work at the different laboratories so as to insure that the extensive amount of work that is planned provides a comprehensive description of the films that form on Alloy 22.

Response: The Project plans to carefully coordinate the testing work performed at different laboratories. Previously, this work was completed under the direction of different project personnel. Currently, one project manager is responsible for all waste package passive film testing ongoing at the various laboratories.

Comment 7-2 (page 84): The Panel recommends the Project seek to identify if critical values of potential, temperature, anion concentration and anion identity exist where the passive film undergoes a significant (discontinuous) change in either structure or composition. Such experiments have been proposed by the Project.

Response: The Project has applied considerable effort towards understanding the composition, structure, and possible existence of critical values for the passive film under a range of environmental conditions such as potential, temperature, and anion concentration. See also the response to Comments 3-10, 3-14, and 3-15.

\subsection{MODELING OF THE PASSIVE FILM AND THE UNIFORM CORROSION RATE OF ALLOY 22}

Comment 7-3 (page 87): Measurement of the parameters of the Butler-Volmer equations describing the rate of hydrogen ion and oxygen reductions on Alloy 22 . These kinetic parameters will serve as input into the General Corrosion Model.

Response: The Project agrees with the Panel that the kinetic parameters of the Butler-Volmer equations, describing the rate of hydrogen ion and oxygen reduction reactions on Alloy 22, need to be measured. As the passive film stability model for Alloy 22 is being used for corroborative purposes, the Project plans to use data generated from an ongoing testing program at the University of Nevada at Reno, funded by the Project through the University of Nevada Systems. Also, a limited data set that was developed under other DOE programs (Nuclear Energy Research Initiative) will be used to evaluate or validate the kinetic parameters in the general corrosion model.

Comment 7-4 (page 87): Measurement of the steady state corrosion rate of Alloy 22 to determine if it is potential independent, as predicted by the Point Defect Model. 
Response: The Project currently is conducting numerous potentiostatic tests to characterize the steady state corrosion rate of Alloy 22. The results of these tests will be used as input or validation of the point defect model. See also the response to Comments 3-12 and 3-27.

Comment 7-5 (page 87): Further development of the Point Defect Model or a new model of passivity to predict the non-steady state performance of Alloy 22 (Urquidi-Macdonald, 2001). The primary purpose is to have a single model that can predict long-term, steady state corrosion rates in the passive state and that can be verified by short term, laboratory tests. In particular, the effect of potential and temperature on uniform corrosion rate in the passive state.

Response: The framework for theoretical development has been completed to extend the point defect model for predicting transient behavior of Alloy 22 in the passive state. Modeling work is underway to further refine the theory to predict the transient behaviors of the corrosion potential and passive current density (uniform corrosion rate) of Alloy 22 as a function of exposure time and major exposure conditions that potentially affect the corrosion behavior such as temperature, $\mathrm{pH}$, and redox couples. When completed, the transient model will allow determination of model parameters using measurements from short term, non-steady state tests, and it will allow the prediction of long term, steady state behaviors of Alloy 22 in the passive state. As stated in the response to Comment 7-3, the Project expects to use data from ongoing testing at University of Nevada at Reno to support and validate the model, as part of the model development effort. 


\section{LOCALIZED CORROSION}

Comment 8-1 (Page 107): The current TSPA model uses data from uncreviced, freshly prepared samples in a few anticipated environments in which Alloy 22 and titanium Grade 7 do not typically exhibit localized corrosion. Therefore, the $\triangle E$ values used in the current TSPA model are unrelated to localized corrosion. This is not an appropriate approach for the prediction of localized corrosion.

Response: The Project understands the comment from the Panel on the prior localized corrosion testing. As mentioned in the response to Comment $2-6$, the Project is experimentally determining the corrosion potential, independent of the critical potential, in a variety of environments spanning a broad range of electrolyte composition, $\mathrm{pH}$, and temperature. The Project also plans to determine the corrosion and critical potentials for base-metal and welded samples representative of actual waste package material, with varying degrees of thermal aging and air oxidation. The ongoing experiments include conditions that are beyond those expected in the Yucca Mountain environment, so that threshold conditions for localized corrosion and margins of resistance can be established. The results of these tests in combination with the ongoing work to define the expected range of credible environments will provide a basis for determining the possibility of localized corrosion.

In the case of Titanium Grade 7, published data will be used in conjunction with the Project data to establish localized corrosion thresholds. 


\section{REFERENCES}

NOTE: References in the text include a DIRS number, and the reference list is sorted by this number. The DIRS number is a unique number that facilitates identifying reference material in Project databases and cross-referencing material among documents.

$124950 \quad$ CRWMS M\&O 1996. Waste Package Closure Weld Development Report. BBA000000-01717-2500-00006 REV 00. Las Vegas, Nevada: CRWMS M\&O. ACC: MOL.19960909.0188.

144229 CRWMS M\&O 2000. General Corrosion and Localized Corrosion of Waste Package Outer Barrier. ANL-EBS-MD-000003 REV 00. Las Vegas, Nevada: CRWMS M\&O. ACC: MOL.20000202.0172.

151564 CRWMS M\&O 2000. Stress Corrosion Cracking of the Drip Shield, the Waste Package Outer Barrier, and the Stainless Steel Structural Material. ANL-EBSMD-000005 REV 00 ICN 01. Las Vegas, Nevada: CRWMS M\&O. ACC: MOL.20001102.0340.

152097 CRWMS M\&O 2000. Analysis of Mechanisms for Early Waste Package Failure. ANL-EBS-MD-000023 REV 02. Las Vegas, Nevada: CRWMS M\&O. ACC: MOL.20001011.0196.

152753 CRWMS M\&O 2000. Waste Package FY-00 Closure Methods Report. TDREBS-ND-000005 REV 00. Las Vegas, Nevada: CRWMS M\&O. ACC: MOL.20001002.0149.

153246 CRWMS M\&O 2000. Total System Performance Assessment for the Site Recommendation. TDR-WIS-PA-000001 REV 00 ICN 01. Las Vegas, Nevada: CRWMS M\&O. ACC: MOL.20001220.0045.

153802 CRWMS M\&O 2000. Waste Package Degradation Process Model Report. TDR-WIS-MD-000002 REV 00 ICN 02. Las Vegas, Nevada: CRWMS M\&O. ACC: MOL.20001228.0229.

153937 CRWMS M\&O 2001. FEPs Screening of Processes and Issues in Drip Shield and Waste Package Degradation. ANL-EBS-PA-000002 REV 01. Las Vegas, Nevada: CRWMS M\&O. ACC: MOL.20010216.0004.

153964 CRWMS M\&O 1999. Software Code: EQ3/6. V7.2b. UCRL-MA-110662 (LSCR198).

154657 BSC (Bechtel SAIC Company) 2001. FY01 Supplemental Science and Performance Analyses, Volume 1: Scientific Bases and Analyses. TDR-MGRMD-000007 REV 00. Las Vegas, Nevada: Bechtel SAIC Company. ACC: MOL.20010712.0062. 
155663 BSC (Bechtel SAIC Company) 2001. Uncanistered Spent Nuclear Fuel Disposal Container System Description Document. SDD-UDC-SE-000001 REV 01 ICN

01. Las Vegas, Nevada: Bechtel SAIC Company. ACC: MOL.20010927.0070.

155753 CRWMS M\&O 2001. Software Users Manual ANSYS Version 5.6.2 Software. Document Number: 10145-UM-5.6.2-00. Las Vegas, Nevada: CRWMS M\&O. ACC: MOL.20010323.0063.

156793 Knapp, M.C. 2001. Waste Package Project FY-01 Closure Methods Report. TDR-EBS-ND-000006 REV 00. Las Vegas, Nevada: Bechtel SAIC Company. ACC: MOL.20011004.0134.

156800 Plinski, M.J. 2001. Waste Package Operations Fabrication Process Report. TDR-EBS-ND-000003 REV 02. Las Vegas, Nevada: Bechtel SAIC Company. ACC: MOL.20011003.0025.

158069 EPRI (Electric Power Research Institute) 2002. Evaluation of the Proposed HighLevel Radioactive Waste Repository at Yucca Mountain Using Total System Performance Assessment, Phase 6. Technical Report 1003031. Palo Alto, California: Electric Power Research Institute. TIC: 252239.

158600 Andresen, P. 2001. Waste Package Stress Corrosion Cracking Assessment and Strategy for Mitigation. Presented to Waste Package Materials Performance Peer Review, Las Vegas, Nevada, May 23, 2001. [Schenectady, New York]: General Electric Corporate Research \& Development. ACC: MOL.20020116.0095.

158781 Beavers, J.A.; Devine, T.M., Jr.; Frankel, G.S.; Jones, R.H.; Kelly, R.G.; Latanision, R.M.; and Payer, J.H. 2002. Final Report, Waste Package Materials Performance Peer Review Panel, February 28, 2002. [Las Vegas, Nevada]: Waste Package Materials Performance Peer Review Panel. ACC: MOL.20020614.0035.

158829 Andresen, P.L.; Young, L.M.; Kim, Y.J.; Emigh, P.W.; Catlin, G.M.; and Martiniano, P.J. 2002. Stress Corrosion Crack Initiation \& Growth Measurements in Environments Relevant to High Level Nuclear Waste Packages. [Schenectady, New York]: GE Global Research Center. ACC: MOL.20020614.0298.

159201 Sridhar, N. 2001. Corrosion Related Studies at the CNWRA. Presentation to the Nuclear Waste Technical Review Board. San Antonio, Texas: Center for Nuclear Waste Regulatory Analyses, Southwest Research Institute. ACC: MOL.20010817.0283.

159298 Briant, C.L. 2002. "Interfacial Segregation in Nickel Base Alloys." Chapter 20 of $A$ Compilation of Special Topic Reports, Waste Package Materials Performance Peer Review. Wong, F.M.G. and Payer, J.H., eds. Las Vegas, Nevada: Waste Package Materials Performance Peer Review Panel. ACC: MOL.20020731.0138. 


\section{DISCLAIMER}

This report was prepared as an account of work sponsored by an agency of the United States Government. Neither the United States Government nor any agency thereof, nor any of their employees, nor any of their contractors, subcontractors or their employees, makes any warranty, express or implied, or assumes any legal liability or responsibility for the accuracy, completeness, or any third party's use or the results of such use of any information, apparatus, product, or process disclosed, or represents that its use would not infringe privately owned rights. Reference herein to any specific commercial product, process, or service by trade name, trademark, manufacturer, or otherwise, does not necessarily constitute or imply its endorsement, recommendation, or favoring by the United States Government or any agency thereof or its contractors or subcontractors. The views and opinions of authors expressed herein do not necessarily state or reflect those of the United States Government or any agency thereof. 
Prepared by:
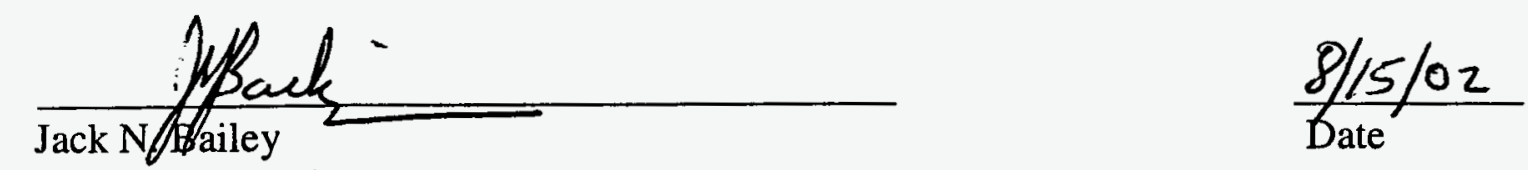

Projects Integration

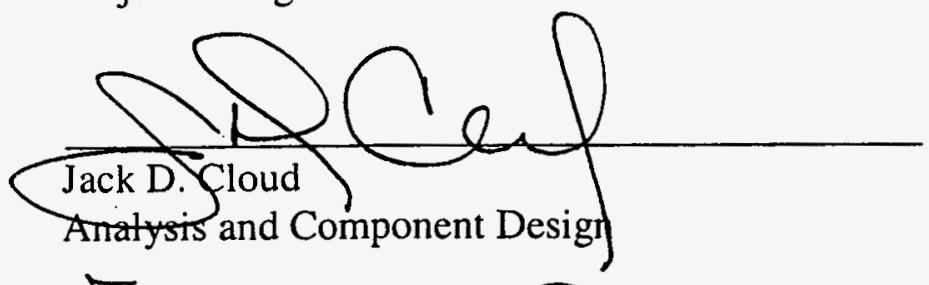

$\frac{8 / 13 / 02}{\text { Date }}$

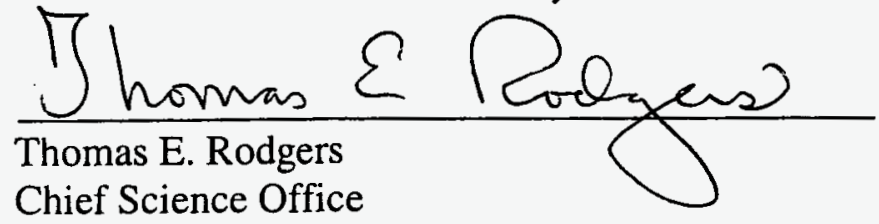

$8 / 13 / 02$

Date

Chief Science Office

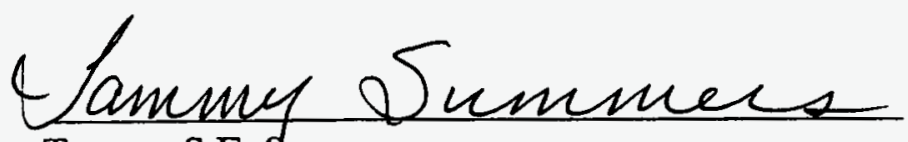

Tammy S.E Summers

Engineered System Waste Package

Reviewed by:

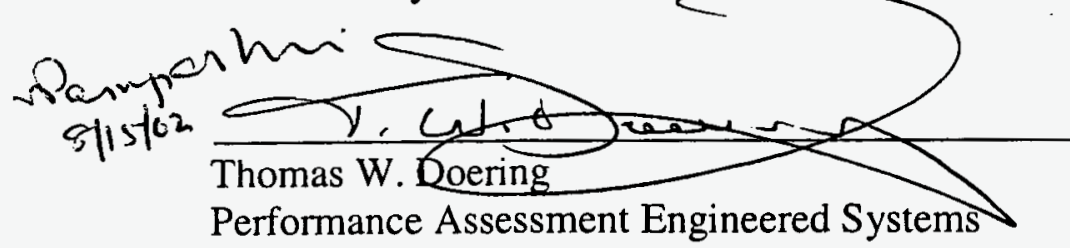

$\frac{8 \cdot 15 \cdot 02}{\text { Date }}$

Approved by:

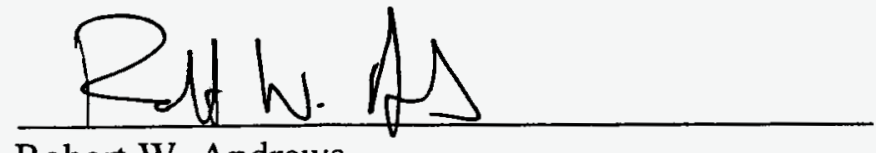

Robert W. Andrews

$\frac{8 / 12 / 02}{\text { Date }}$

Performance Assessment

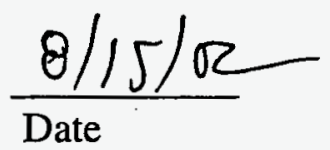




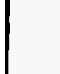

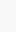

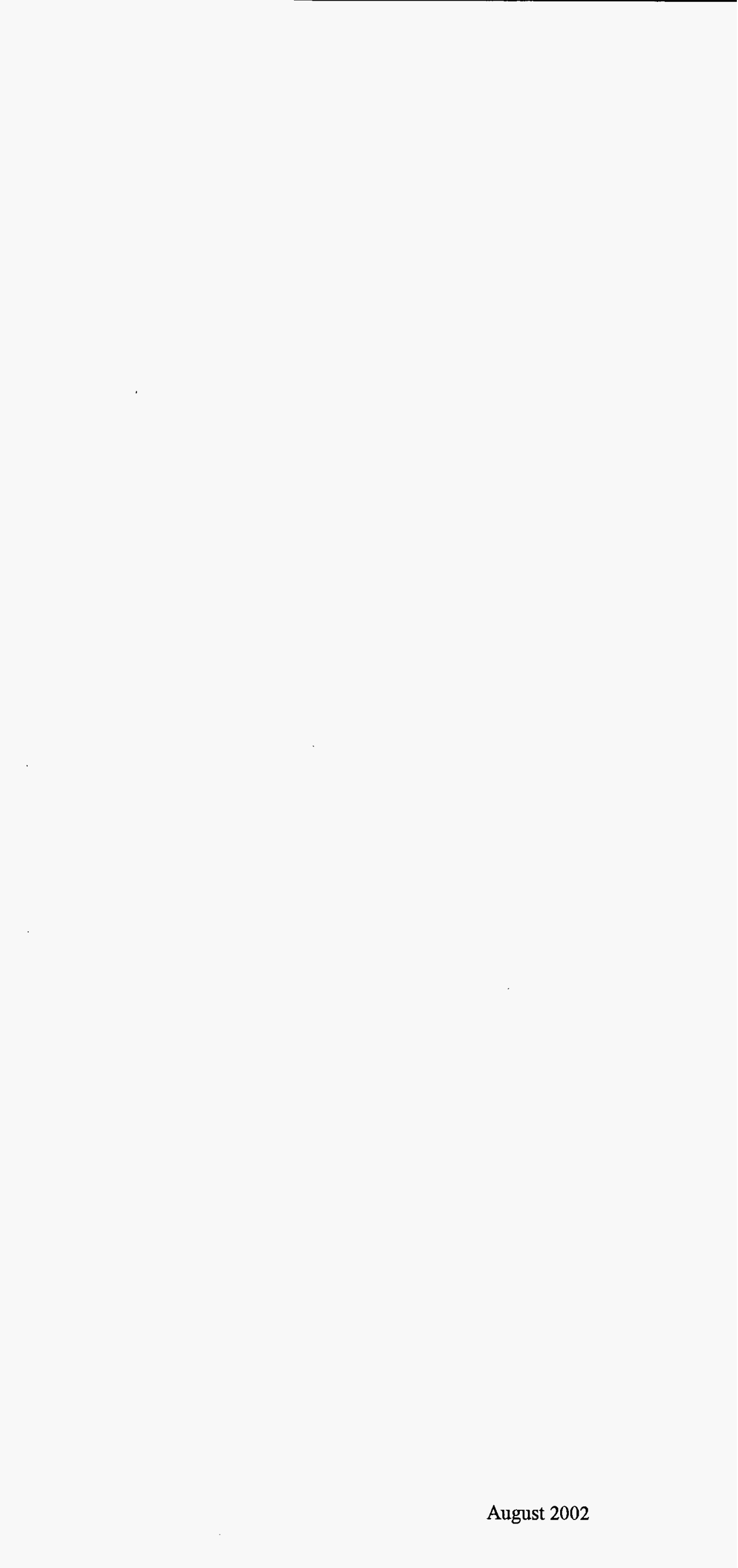

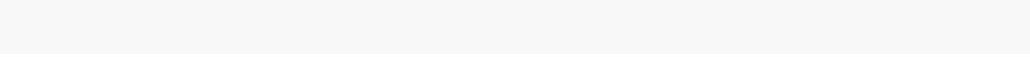




\section{CHANGE HISTORY}

Revision Interim Effective

Number Change No. Date

00
0

\section{Description of Change}

Initial issue. 
INTENTIONALLY LEFT BLANK 


\section{ACKNOWLEDGMENTS}

The evaluation of the findings and recommendations in the Final Report: Waste Package Materials Performance Peer Review Panel (Beavers et al. 2002 [DIRS 158781]), required input from across the Management and Operating Contractor. Principal contributors to the evaluation included: Tammy Summers, Raul Rebak, Gregory Gdowski, Gabriel Ilevbare, and Joseph Farmer (Lawrence Livermore National Laboratory); Gerald Gordon (Framatome ANP); Nancy Williams, Jean Younker, Jack Cloud, Glen Hanson, Martha Pendleton, and V. Pasu Pasupathi (Bechtel SAIC Company, LLC); Bryan Bullard and Kevin Mon (Framatome ANP DE\&S); Jack Bailey (Beckman and Associates) and Joon Lee (Sandia National Laboratory).

The final document benefited from the thoughtful reviews and suggested modifications from Robert Andrews, V. Pasu Pasupathi, Thomas Doering, and James Boone (Bechtel SAIC Company, LLC), Donald Beckman (Beckman and Associates), Thomas Cotton (JK Research Associates, Inc.), Stephen Hanauer (U.S. Department of Energy), and Frank Wong (Stone and Webster). 
INTENTIONALLY LEFT BLANK 


\section{OVERVIEW}

At the direction of the Yucca Mountain Site Characterization Office, Bechtel SAIC Company, LLC (BSC) convened an independent Waste Package Materials Performance Peer Review (the Panel) to review the technical basis for evaluating the long-term performance of waste package materials in the proposed repository at Yucca Mountain, Nevada. The overall objectives of the peer review were to:

- Review the current bases for predicting the long-term corrosion performance of the Alloy 22 waste package and Titanium Grade 7 drip shield materials

- Review the current and planned experimental and modeling programs

- Assess the adequacy of the experimental and modeling programs

- Make recommendations that would strengthen the program.

In the Final Report: Waste Package Materials Performance Peer Review Panel (Beavers et al. 2002 [DIRS 158781]), the Panel summarized technical issues for assessing the performance of waste package materials, their evaluation of the technical basis for understanding these issues, and their evaluation of approaches and plans to resolve these issues. The Panel findings were made from the perspective of long-term materials performance. The scope of the Panel's review did not include broader considerations such as total system performance assessment, the level of information needed at different stages of the decision making process (e.g., site recommendation and license application), or repository design and operations. To provide a complete perspective addressing the recommendations for strengthening the experimental, modeling, design, and fabrication activities, BSC has responded in the context of these broader considerations.

In the final report, the Panel concluded that the current waste package design likely will meet the performance criteria for the repository if some technical issues are resolved favorably. This conclusion depended on waste package and drip shield performance and did not consider other aspects of the system that contribute to meeting regulatory performance criteria. From a broader perspective, conclusions on the overall ability of the system to meet such criteria must also take into account these other aspects of the system. At the repository system level, the results of the Total System Performance Assessment for Site Recommendation (CRWMS M\&O 2000 [DIRS 153246]) indicate that a repository at the Yucca Mountain site is predicted to meet radiation standards designed to protect public health and safety over the 10,000-year regulatory period. These projections of long-term system performance include extrapolations of relatively shortterm corrosion data from an extensive database (containing many conservatisms). BSC believes that the uncertainties in these long-term extrapolations of waste package material performance are adequately captured in the performance assessment calculations developed to support this stage of the decision making process. Furthermore, BSC believes that the probability of favorable resolution of the issues identified by the Panel is sufficiently high to warrant proceeding to the preparation of a license application. The ongoing and planned experimental work and modeling will continue to strengthen the technical basis for the extrapolations of waste package performance and will improve the understanding of the uncertainties in estimates of waste package material performance for the license application. 
In its final report, the Panel also concluded that confidence in the long-term performance of Alloy 22 can be substantially increased through further experiments and analyses. The Panel recommended that this work be undertaken. BSC agrees that further testing and analysis will increase the confidence in long-term extrapolations of waste package performance.

Where appropriate, responses to recommendations by the Panel address the time frame for additional work in the context of the overall schedule of potential licensing, design, construction, and performance confirmation. Some of the technical activities discussed in the final report are ongoing and will improve the technical basis supporting the total system performance assessment and design concepts for the license application. The Project materials testing program and waste package design activities will continue to evolve. For example, ongoing efforts are focused on developing preliminary material and fabrication specifications. For the license application, it will be sufficient to show that a representative material performs acceptably. As information is gathered, adjustments to these specification can and, if necessary, will be made during the development of the final specifications. The final specifications for containers intended for handling spent fuel and emplacement are needed some time in advance of initial emplacement that occurs in the year 2010 under the current schedule.

This report, Evaluation of the Final Report: Waste Package Materials Performance Peer Review Panel, documents the comments provided in the final report and the responses by BSC to those comments. The responses were based on input from scientists representing BSC and several of the National Laboratories. While the Panel relied primarily on published reports to develop the recommendations, the BSC responses consider published results and the results of ongoing experimental work. The comments and responses were organized consistent with the organization of the final report. In the final report, the main comments are summarized in the Overview and in Sections 2 and 3. Several additional comments, presented only in latter portions of the final report (Sections 4 through 10), also are addressed. If a comment was presented in more than one place, the initial comment was addressed, and reference was made to the later comments. In this document, excerpts of comments quoted from the final report are presented in italics, and the responses by BSC are presented in plain text. Table 1 summarizes the work scope to address waste package peer review recommendations. Comment numbers correlate to those discussed within the main body of this report.

Table 1. Work Scope to Address Waste Package Peer Review Recommendations.

\begin{tabular}{|c|l|c|l|}
\hline $\begin{array}{c}\text { Comment } \\
\text { No. }\end{array}$ & \multicolumn{1}{|c|}{ Recommendation } & $\begin{array}{c}\text { Project } \\
\text { Position }\end{array}$ & Project Status \\
\hline $2-1$ & $\begin{array}{l}\text { Further tests and analyses to increase } \\
\text { confidence in the long-term performance } \\
\text { of Alloy 22. }\end{array}$ & Agree & $\begin{array}{l}\text { The ongoing and planned testing program } \\
\text { is adequate. }\end{array}$ \\
\hline $2-2$ & $\begin{array}{l}\text { Do not use Titanium Grade 7 if it is found } \\
\text { to be susceptible to stress corrosion } \\
\text { cracking (SSC). }\end{array}$ & $\begin{array}{c}\text { Partially } \\
\text { Agree }\end{array}$ & $\begin{array}{l}\text { The Project has recognized that Titanium } \\
\text { Grade 7 is susceptible to SCC, but does } \\
\text { not believe that SCC is an important issue } \\
\text { for the intended performance of the drip } \\
\text { shield. However, alternative concepts are } \\
\text { being evaluated. }\end{array}$ \\
\hline
\end{tabular}




\begin{tabular}{|c|c|c|c|}
\hline $\begin{array}{l}\text { Comment } \\
\text { No. }\end{array}$ & Recommendation & $\begin{array}{l}\text { Project } \\
\text { Position }\end{array}$ & Project Status \\
\hline $2-3$ & $\begin{array}{l}\text { Develop a strong technical basis for the } \\
\text { three conditions on the surface of metal: } \\
\text { accumulated dust and particulate, } \\
\text { deposits and scale, and moisture. Form } \\
\text { an interdisciplinary team of experts to } \\
\text { determine the range of environments. }\end{array}$ & Agree & $\begin{array}{l}\text { Specific testing and analyses are } \\
\text { discussed in Comments } 2-17,2-27,3-1 \text {, } \\
3-2,3-13 \text {, and } 3-16 \text {. The Project plans to } \\
\text { form a team to evaluate the range of } \\
\text { environments. }\end{array}$ \\
\hline $2-4$ & $\begin{array}{l}\text { Gap between fabrication and design. } \\
\text { Specifically, work is required on weld and } \\
\text { weld repair processes. }\end{array}$ & Agree & $\begin{array}{l}\text { The Project agrees; work on weld and } \\
\text { weld repair processes is discussed in } \\
\text { Comment } 2-16 \text {. }\end{array}$ \\
\hline $2-5$ & $\begin{array}{l}\text { Uniform corrosion: Two phenomena could } \\
\text { jeopardize long-term behavior: Sulfur } \\
\text { segregation and transpassive corrosion. }\end{array}$ & Agree & $\begin{array}{l}\text { Testing and analyses indicate that thermal } \\
\text { segregation is not an issue under } \\
\text { repository relevant conditions and that the } \\
\text { effect of production of hydrogen peroxide } \\
\text { and other products is small. Anodic sulfur } \\
\text { segregation to be looked at but can } \\
\text { continue beyond LA. See Comment 3-7. } \\
\text { Effect of ferric ions on corrosion to be } \\
\text { tested prior to LA. See Comment 3-12. }\end{array}$ \\
\hline $2-6$ & $\begin{array}{l}\text { Localized corrosion: Need a more } \\
\text { rigorous determination of critical } \\
\text { potentials. }\end{array}$ & Agree & $\begin{array}{l}\text { Additional work is planned as part of the } \\
\text { model validation effort; additional work will } \\
\text { be added in FY } 2003 \text {. }\end{array}$ \\
\hline $2-7$ & $\begin{array}{l}\text { SCC: Consider alternative models for } \\
\text { SCC. Replace the threshold stress } \\
\text { component of the slip dissolution model } \\
\text { with the threshold stress intensity factor } \\
\text { model, develop constants specific to Alloy } \\
22 \text {. }\end{array}$ & Agree & $\begin{array}{l}\text { Alternate models will be addressed in an } \\
\text { update to the SCC Analysis Model Report } \\
\text { in FY } 2003 \text {. The Project will use threshold } \\
\text { stress intensity factors for the welded } \\
\text { portions of the waste package containing } \\
\text { preexisting flaws. }\end{array}$ \\
\hline $2-8$ & $\begin{array}{l}\text { Thoroughly evaluate the effectiveness of } \\
\text { heat treatment for stress mitigation. }\end{array}$ & Agree & $\begin{array}{l}\text { Testing of the FY } 2000 \text { mockup is planned } \\
\text { for FY } 2003 \text {. The work will continue as an } \\
\text { integrated and iterative process beyond } \\
\text { the LA. }\end{array}$ \\
\hline $2-9$ & $\begin{array}{l}\text { Evaluate SCC of Alloy } 22 \text { with different } \\
\text { stages of aging and environments } \\
\text { containing trace impurities, such as lead. }\end{array}$ & Agree & $\begin{array}{l}\text { Additional aging studies are planned for } \\
\text { FY } 2003 \text {. Testing can continue beyond } \\
\text { LA because stress mitigation should } \\
\text { remove tensile stresses. }\end{array}$ \\
\hline $2-10$ & $\begin{array}{l}\text { Testing and analysis at high temp needed } \\
\text { before a decision is made on thermal } \\
\text { operating modes. }\end{array}$ & Agree & $\begin{array}{l}\text { The ongoing and planned testing program } \\
\text { is adequate. }\end{array}$ \\
\hline $2-11$ & $\begin{array}{l}\text { Determine the effects of alloy composition } \\
\text { within specified ranges of Alloy } 22 \text {. }\end{array}$ & Agree & $\begin{array}{l}\text { Samples for analysis are expected from } \\
\text { the Base and Weld Material Variability } \\
\text { Study in September } 2003 \text {. Aging and } \\
\text { some evaluation planned in FY } 2004 \text {. }\end{array}$ \\
\hline $2-12$ & $\begin{array}{l}\text { Do not designate materials less corrosion } \\
\text { resistant than Alloy } 22 \text { unless there is } \\
\text { credible evidence that a less resistant } \\
\text { alloy will work. }\end{array}$ & Agree & $\begin{array}{l}\text { The Project will not select metals less } \\
\text { corrosion resistant than Alloy } 22 \text { unless } \\
\text { their performance can be demonstrated. }\end{array}$ \\
\hline $2-13$ & $\begin{array}{l}\text { Include a backup and comparison alloys } \\
\text { in certain tests performed on Alloy } 22 \text {. }\end{array}$ & Agree & $\begin{array}{l}\text { Current experiments include other alloys } \\
\text { in addition to Alloy } 22 \text {. }\end{array}$ \\
\hline $2-14$ & $\begin{array}{l}\text { Provide adequate resources to } \\
\text { substantially build confidence in waste } \\
\text { package performance. }\end{array}$ & Agree & $\begin{array}{l}\text { The Project believes that adequate } \\
\text { resources are available and properly } \\
\text { allocated. }\end{array}$ \\
\hline $2-15$ & $\begin{array}{l}\text { Coordinate analysis and testing program } \\
\text { between design/fabrication and } \\
\text { materials/corrosion testing. }\end{array}$ & Agree & $\begin{array}{l}\text { The Project will coordinate these } \\
\text { activities. }\end{array}$ \\
\hline
\end{tabular}




\begin{tabular}{|c|c|c|c|}
\hline $\begin{array}{c}\text { Comment } \\
\text { No. }\end{array}$ & Recommendation & $\begin{array}{l}\text { Project } \\
\text { Position }\end{array}$ & Project Status \\
\hline $2-16$ & Develop and validate weld procedures. & Agree & $\begin{array}{l}\text { Work is ongoing and will continue post- } \\
\text { LA. }\end{array}$ \\
\hline $2-17$ & $\begin{array}{l}\text { Complete a comprehensive experimental } \\
\text { and analytical modeling program to } \\
\text { establish realistic bounds for the three } \\
\text { environmental conditions. }\end{array}$ & Agree & $\begin{array}{l}\text { A comprehensive program is ongoing. } \\
\text { Some additional testing and analysis to } \\
\text { address microbiologically influenced } \\
\text { corrosion is planned for FY } 2003 \text {. }\end{array}$ \\
\hline $2-18$ & $\begin{array}{l}\text { Determine the corrosion behavior within } \\
\text { realistic environments and beyond the } \\
\text { realistic range for each of the corrosion } \\
\text { modes. }\end{array}$ & Agree & $\begin{array}{l}\text { Autoclave tests planned in FY } 2003 \text { to } \\
\text { perform tests at higher temperatures. }\end{array}$ \\
\hline $2-19$ & $\begin{array}{l}\text { Complete experiments and analysis of } \\
\text { radiolysis from gamma radiation. }\end{array}$ & Agree & Summarize existing data. \\
\hline $2-20$ & $\begin{array}{l}\text { Evaluate Corrosion potential over long } \\
\text { periods. }\end{array}$ & Agree & Work is ongoing. \\
\hline $2-21$ & $\begin{array}{l}\text { Cr-Mo depletion and equal priority } \\
\text { treatment of long-range ordering. }\end{array}$ & $\begin{array}{l}\text { Partially } \\
\text { Agree }\end{array}$ & $\begin{array}{l}\text { Work is ongoing. Additional analyses of } \\
\text { the effects of cold work are planned for FY } \\
2003 \text {. See Comments } 3-5 \text { and 3-6. }\end{array}$ \\
\hline $2-22$ & $\begin{array}{l}\text { Measure the effects of sulfur and } \\
\text { phosphorous in relevant environments, } \\
\text { model and/or measure the rate of sulfur } \\
\text { accumulation on the surface, and evaluate } \\
\text { the potential for grain boundary impurity } \\
\text { segregation. }\end{array}$ & Agree & $\begin{array}{l}\text { A theoretical evaluation of anodic } \\
\text { segregation of sulfur is needed as a } \\
\text { minimum. This work can continue after } \\
\text { LA because detrimental effects of sulfur } \\
\text { segregation can be eliminated by a } \\
\text { reduction of sulfur content in the alloy, if } \\
\text { needed. }\end{array}$ \\
\hline $2-23$ & $\begin{array}{l}\text { Evaluate the effectiveness of tensile } \\
\text { stress reduction for SCC control. This } \\
\text { may not be easily accomplished. }\end{array}$ & Agree & $\begin{array}{l}\text { All surfaces of the FY } 2000 \text { mockup will } \\
\text { be analyzed for stress state with the lids } \\
\text { installed and after annealing is complete. } \\
\text { Additional testing of future full-scale } \\
\text { prototypes will be considered. }\end{array}$ \\
\hline $2-24$ & $\begin{array}{l}\text { Analyze likely location, distribution, and } \\
\text { geometry of stress corrosion crack growth } \\
\text { and consequence. }\end{array}$ & Agree & Work is ongoing. \\
\hline $2-25$ & Hydrogen embrittlement of Alloy 22 & Agree & $\begin{array}{l}\text { Although no evidence of Alloy } 22 \\
\text { hydrogen embrittlement susceptibility has } \\
\text { been seen, a limited amount of testing will } \\
\text { be done to confirm this. }\end{array}$ \\
\hline $2-26$ & $\begin{array}{l}\text { Improve integration among design, } \\
\text { engineering, analysis, modeling, and } \\
\text { testing. }\end{array}$ & Agree & Organizational changes implemented. \\
\hline $2-27$ & $\begin{array}{l}\text { Focus and integrate efforts to determine } \\
\text { the range of aqueous environments on } \\
\text { waste package; design and fabrication of } \\
\text { waste package for corrosion resistance. }\end{array}$ & Agree & $\begin{array}{l}\text { The Project will ensure that the } \\
\text { appropriate expertise is focused on } \\
\text { determining the aqueous environment; } \\
\text { process controls in place for LA will } \\
\text { improve integration. }\end{array}$ \\
\hline $2-28$ & $\begin{array}{l}\text { Increase involvement of technical experts } \\
\text { form academia and industry. }\end{array}$ & $\begin{array}{l}\text { Partially } \\
\text { Agree }\end{array}$ & $\begin{array}{l}\text { The Project has and will continue to } \\
\text { involve experts from outside the Project. }\end{array}$ \\
\hline $2-29$ & Establish an external advisory board. & Disagree & $\begin{array}{l}\text { Not planned at this time. The Project has } \\
\text { used a range of external review Boards in } \\
\text { the past and will continue to do so in the } \\
\text { future, when warranted. }\end{array}$ \\
\hline $3-1$ & $\begin{array}{l}\text { Expand current work on understanding } \\
\text { the effects of interactions between } \\
\text { seepage water and hot metal surface. }\end{array}$ & Agree & This work is ongoing. \\
\hline
\end{tabular}




\begin{tabular}{|c|c|c|c|}
\hline $\begin{array}{l}\text { Comment } \\
\text { No. }\end{array}$ & Recommendation & $\begin{array}{l}\text { Project } \\
\text { Position }\end{array}$ & Project Status \\
\hline $3-2$ & $\begin{array}{l}\text { Continue focus on developing tech basis } \\
\text { for environmental extremes. }\end{array}$ & Agree & This work is ongoing. \\
\hline $3-3$ & $\begin{array}{l}\text { Improve coupling between engineered } \\
\text { barrier system, thermal/hydrological/ } \\
\text { chemical, environment calculations, and } \\
\text { experimental results. }\end{array}$ & Agree & $\begin{array}{l}\text { A team of technical staff from the relevant } \\
\text { technical disciplines has been assembled } \\
\text { to establish the environment on the waste } \\
\text { packages. }\end{array}$ \\
\hline $3-4$ & $\begin{array}{l}\text { Characterize possible metabolites and } \\
\text { their effects on the engineered materials, } \\
\text { including steel components of the } \\
\text { repository. }\end{array}$ & $\begin{array}{l}\text { Partially } \\
\text { Agree }\end{array}$ & $\begin{array}{l}\text { Viability of microbes included in waste } \\
\text { package modeling; ongoing testing is } \\
\text { planned to determine effects of microbes } \\
\text { on localized corrosion of Alloy } 22 \text {. }\end{array}$ \\
\hline $3-5$ & $\begin{array}{l}\text { Determine whether chromium and } \\
\text { molybdenum depletion occurs near grain } \\
\text { boundaries. If this occurs, determine the } \\
\text { temperature and time relationship for this } \\
\text { depletion. }\end{array}$ & Disagree & $\begin{array}{l}\text { The Project believes that fully aged } \\
\text { material is bounding. }\end{array}$ \\
\hline $3-6$ & $\begin{array}{l}\text { Give long range ordering equal } \\
\text { importance to that given precipitation. }\end{array}$ & Agree & $\begin{array}{l}\text { Thick prototypical welds and cold work are } \\
\text { planned to be added to aging studies in } \\
\text { FY 2003. }\end{array}$ \\
\hline $3-7$ & $\begin{array}{l}\text { Investigate the effects of surface } \\
\text { segregation of sulfur and transpassivity on } \\
\text { passive film. }\end{array}$ & $\begin{array}{c}\text { Agree, if } \\
\text { enough sulfur } \\
\text { accumulates } \\
\text { on the metal } \\
\text { oxide surface. } \\
\end{array}$ & $\begin{array}{l}\text { This work can be addressed after LA } \\
\text { because detrimental effects of sulfur } \\
\text { segregation can be eliminated by a } \\
\text { reduction of sulfur content in the alloy, if } \\
\text { needed. }\end{array}$ \\
\hline $3-8$ & $\begin{array}{l}\text { Investigate the two causes of surface } \\
\text { segregation of sulfur. }\end{array}$ & \begin{tabular}{|c|} 
Agree, if \\
enough sulfur \\
accumulates \\
on the metal \\
oxide surface. \\
\end{tabular} & See responses to Comments $2-5$ and $3-7$. \\
\hline $3-9$ & $\begin{array}{l}\text { Determine the likelihood of radiolysis of } \\
\text { water causing transpassive dissolution of } \\
\text { Alloy } 22 \text {. }\end{array}$ & Disagree & $\begin{array}{l}\text { The Project believes these effects are } \\
\text { small. }\end{array}$ \\
\hline $3-10$ & $\begin{array}{l}\text { Investigate changes in structure and } \\
\text { composition of high temp oxide films. }\end{array}$ & Agree & $\begin{array}{l}\text { This work is planned in FY } 2003 \text {. Some } \\
\text { tests will be completed prior to LA. }\end{array}$ \\
\hline $3-11$ & $\begin{array}{l}\text { Test uniform corrosion in the LTCTF at } \\
\text { temperatures above } 90^{\circ} \mathrm{C} \text {. }\end{array}$ & Agree & $\begin{array}{l}\text { Additional tests are planned for FY } 2004 \\
\text { and will continue beyond the LA. }\end{array}$ \\
\hline $3-12$ & $\begin{array}{l}\text { Test uniform corrosion rate of Alloy } 22 \text { at } \\
\text { high passive potentials. }\end{array}$ & Agree & $\begin{array}{l}\text { Additional work will commence in FY } \\
2003 \text {. }\end{array}$ \\
\hline $3-13$ & $\begin{array}{l}\text { Undertake studies of localized corrosion } \\
\text { propagation and arrest. }\end{array}$ & Agree & Thin film solution studies are ongoing. \\
\hline $3-14$ & $\begin{array}{l}\text { Examine the effects of metal surface } \\
\text { condition on localized corrosion. }\end{array}$ & Agree & $\begin{array}{l}\text { Experiments to evaluate this effect are } \\
\text { planned to be initiated prior to LA for } \\
\text { insights and continue after LA. }\end{array}$ \\
\hline $3-15$ & $\begin{array}{l}\text { Address the influence of structural } \\
\text { changes on localized corrosion. Perform } \\
\text { experiments for determining } E_{R, C R E V} \text { on } \\
\text { welded samples. }\end{array}$ & Agree & $\begin{array}{l}\text { The Project has some limited data that do } \\
\text { not show accelerated or localized } \\
\text { corrosion effects. General and localized } \\
\text { corrosion experiments of thicker multipass } \\
\text { welds are ongoing. }\end{array}$ \\
\hline $3-16$ & $\begin{array}{l}\text { Examine localized corrosion for most } \\
\text { relevant conditions in wet environment in } \\
\text { contact with metal surfaces. }\end{array}$ & Agree & Work is ongoing. \\
\hline $3-17$ & $\begin{array}{l}\text { Establish and improve the maximum } \\
\text { sensitivity to crack growth in the threshold } \\
\text { stress intensity factor. }\end{array}$ & Agree & $\begin{array}{l}\text { Sensitivity to crack initiation and } \\
\text { propagation has been established using } \\
\text { fatigued pre-cracked compact tension } \\
\text { specimens. }\end{array}$ \\
\hline
\end{tabular}




\begin{tabular}{|c|c|c|c|}
\hline $\begin{array}{l}\text { Comment } \\
\text { No. }\end{array}$ & Recommendation & $\begin{array}{l}\text { Project } \\
\text { Position }\end{array}$ & Project Status \\
\hline $3-18$ & $\begin{array}{l}\text { Replace the threshold stress criterion with } \\
\text { threshold stress intensity factor. }\end{array}$ & Agree & $\begin{array}{l}\text { Threshold stress intensity factors will be } \\
\text { used for the welded portions of the waste } \\
\text { package that contain preexisting flaws. }\end{array}$ \\
\hline $3-19$ & $\begin{array}{l}\text { Develop constants specific }(A \text { and } n) \text { to } \\
\text { Alloy } 22 \text { for the film rupture/slip dissolution } \\
\text { model. }\end{array}$ & Agree & $\begin{array}{l}\text { Preliminary constants specific to Alloy } 22 \\
\text { have been developed. }\end{array}$ \\
\hline $3-20$ & $\begin{array}{l}\text { Thoroughly evaluate the issue of heat } \\
\text { treatment for stress mitigation and alloy } \\
\text { stability. }\end{array}$ & Agree & Work is ongoing. \\
\hline $3-21$ & $\begin{array}{l}\text { Demonstrate approach to stress mitigation } \\
\text { with finite element analysis and testing of } \\
\text { prototypes. }\end{array}$ & Agree & $\begin{array}{l}\text { Finite element models have been } \\
\text { developed. Stress mitigation techniques } \\
\text { are being evaluated. When the evaluation } \\
\text { is completed, prototype testing will be } \\
\text { conducted. }\end{array}$ \\
\hline $3-22$ & $\begin{array}{l}\text { Evaluate the effects of ordering, grain } \\
\text { boundary segregation, and impurity } \\
\text { segregation on SCC. }\end{array}$ & Agree & $\begin{array}{l}\text { Work is ongoing to evaluate mechanical } \\
\text { property changes and potential changes } \\
\text { in general and localized corrosion. } \\
\text { Experiments on SCC resistance have } \\
\text { been given a relatively low priority at this } \\
\text { point in the program because of plans to } \\
\text { mitigate residual stress. }\end{array}$ \\
\hline $3-23$ & $\begin{array}{l}\text { Complete experiments to explore } \\
\text { hydrogen embrittlement for Alloy } 22 \text {. }\end{array}$ & Agree & See response to Comment $2-25$ \\
\hline $3-24$ & $\begin{array}{l}\text { Carry out a program to qualify weld filler } \\
\text { metal. }\end{array}$ & Agree & $\begin{array}{l}\text { The Project has welds that are in long } \\
\text { term testing. This testing will continue. } \\
\text { Additionally, the Weld Base and Filler } \\
\text { Compositional Variability Study is planned } \\
\text { to address this issue. This is the first step } \\
\text { in a program to qualify weld filler metal } \\
\text { that will continue beyond LA. See } \\
\text { response to Comment 3-26. }\end{array}$ \\
\hline $3-25$ & $\begin{array}{l}\text { Evaluate alternate weld processes for } \\
\text { closure weld. }\end{array}$ & Agree & $\begin{array}{l}\text { This work has been ongoing since } 1996 . \\
\text { Two alternative evaluations have been } \\
\text { performed to date which both } \\
\text { recommended cold wire, tungsten inert } \\
\text { gas welding as the preferred method. In } \\
\text { addition, a panel of external experts has } \\
\text { been tasked with reviewing the } \\
\text { appropriateness of the technology } \\
\text { selection. }\end{array}$ \\
\hline $3-26$ & $\begin{array}{l}\text { Determine compositional effects within the } \\
\text { chemical specification of Alloy } 22 \text {. }\end{array}$ & Agree & $\begin{array}{l}\text { The Project plans to initiate tests of the } \\
\text { variability in base metal-weld metal } \\
\text { composition in FY } 2003 \text {. }\end{array}$ \\
\hline $3-27$ & $\begin{array}{l}\text { Complete four recommended analyses to } \\
\text { investigate the effects of radiation. }\end{array}$ & Disagree & $\begin{array}{l}\text { Based on available data, the Project } \\
\text { considers these analyses to be a low } \\
\text { priority. }\end{array}$ \\
\hline $3-28$ & $\begin{array}{l}\text { Continue electrochemical measurements } \\
\text { in the LTCTF. }\end{array}$ & Agree & These tests are continuing. \\
\hline $5-1$ & $\begin{array}{l}\text { Complete corrosion studies on ground } \\
\text { control structures. }\end{array}$ & Agree & $\begin{array}{l}\text { Additional work is planned to investigate } \\
\text { the effect of corrosion products from } \\
\text { ground support with water drip tests under } \\
\text { elevated temperatures and constant } \\
\text { relative humidity. }\end{array}$ \\
\hline
\end{tabular}




\begin{tabular}{|c|c|c|c|}
\hline $\begin{array}{c}\text { Comment } \\
\text { No. }\end{array}$ & Recommendation & $\begin{array}{l}\text { Project } \\
\text { Position }\end{array}$ & Project Status \\
\hline $6-1$ & $\begin{array}{l}\text { Develop relationship between grain size, } \\
\text { time, and temperature, using Haynes } \\
\text { alloy. }\end{array}$ & $\begin{array}{c}\text { Agree, but low } \\
\text { priority }\end{array}$ & $\begin{array}{l}\text { Many aged samples have been examined } \\
\text { and no gross changes in grain size have } \\
\text { been observed. }\end{array}$ \\
\hline $6-2$ & $\begin{array}{l}\text { Procure a program heat of material with } \\
\text { desired level of elements within alloy } \\
\text { specification. }\end{array}$ & $\begin{array}{l}\text { Agree to } \\
\text { consider }\end{array}$ & $\begin{array}{l}\text { Compositional variability of existing } \\
\text { samples will be determined. These data } \\
\text { will be used to evaluate potential heat-to- } \\
\text { heat variability complications and to } \\
\text { determine future testing needs. }\end{array}$ \\
\hline $7-1$ & $\begin{array}{l}\text { Improve the coordination of } \\
\text { testing/analysis at different laboratories. }\end{array}$ & Agree & $\begin{array}{l}\text { The Project plans to carefully coordinate } \\
\text { this work. }\end{array}$ \\
\hline $7-2$ & $\begin{array}{l}\text { Identify if critical values of potential, } \\
\text { temperature, anion concentration, and } \\
\text { anion identity exist where the passive film } \\
\text { undergoes significant (discontinuous) } \\
\text { change in either structure or composition. }\end{array}$ & Agree & This work is ongoing. \\
\hline $7-3$ & $\begin{array}{l}\text { Measurement of parameters of the Butler- } \\
\text { Volmer equations describing the rate of } \\
\text { hydrogen ion and oxygen reductions in } \\
\text { Alloy } 22 \text {. }\end{array}$ & Agree & $\begin{array}{l}\text { The Project will use the results of ongoing } \\
\text { testing from outside the Project. }\end{array}$ \\
\hline $7-4$ & $\begin{array}{l}\text { Measurement of steady-state corrosion } \\
\text { rate of Alloy } 22 \text { to determine if it is } \\
\text { potential dependent, as predicted by the } \\
\text { point defect model. }\end{array}$ & Agree & Potentiostatic tests are ongoing. \\
\hline $7-5$ & $\begin{array}{l}\text { Further development of point defect model } \\
\text { or other model for prediction of the non- } \\
\text { steady state performance of Alloy } 22 \text {. }\end{array}$ & Agree & $\begin{array}{l}\text { The theoretical framework has been } \\
\text { completed to extend the model. Modeling } \\
\text { work is underway to refine the model. }\end{array}$ \\
\hline $8-1$ & $\begin{array}{l}\text { Uncreviced, freshly prepared samples in } \\
\text { environments not showing localized } \\
\text { corrosion not an appropriate approach for } \\
\text { predicting localized corrosion. }\end{array}$ & Agree & This work is ongoing. \\
\hline
\end{tabular}

Note: FY = fiscal year. 
INTENTIONALLY LEFT BLANK 


\section{CONTENTS}

Page

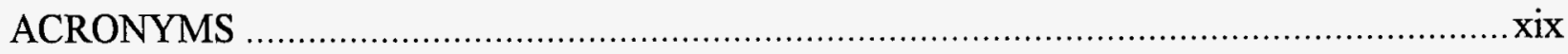

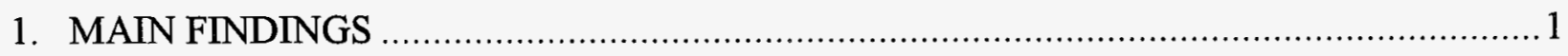

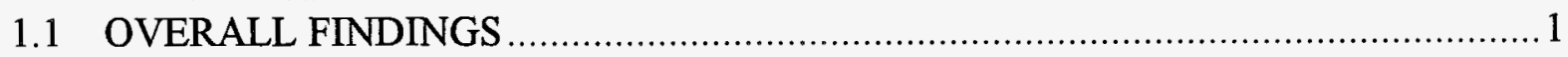

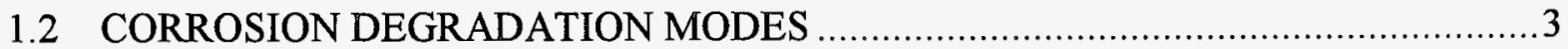

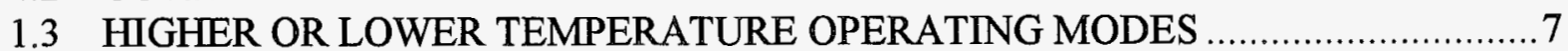

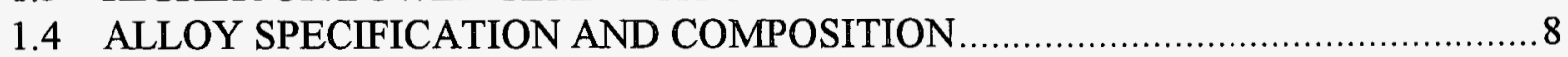

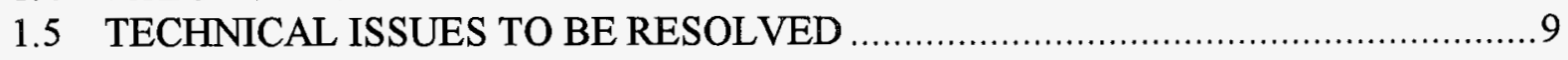

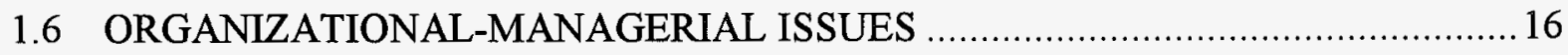

2. SUMMARY OF DEGRADATION MODES AND CONTRIBUTING FACTORS ..............19

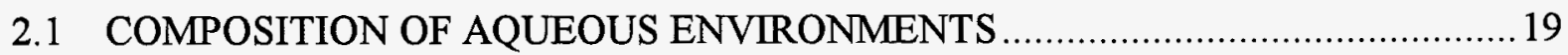

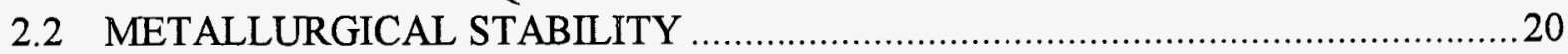

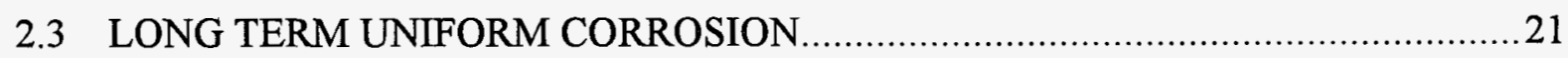

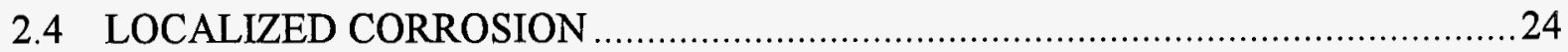

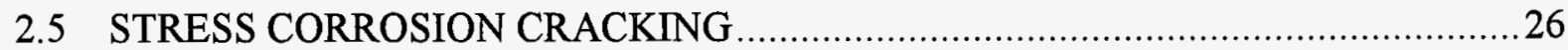

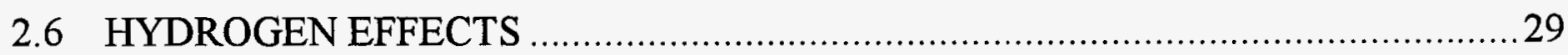

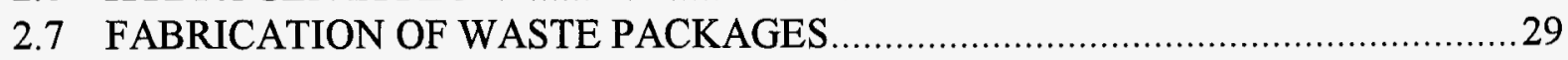

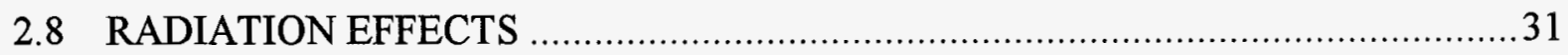

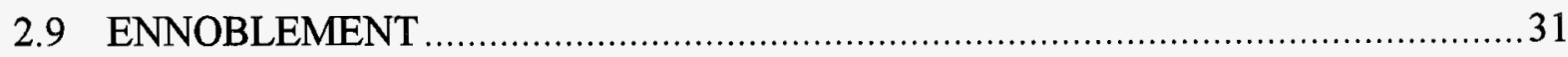

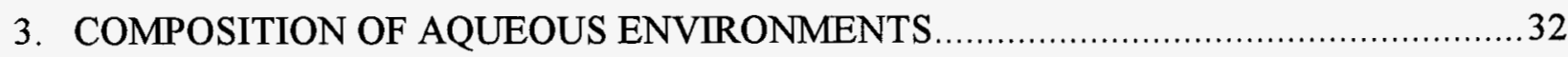

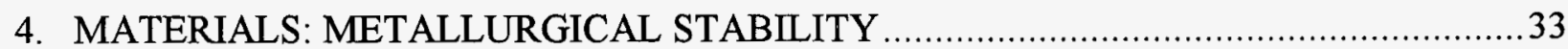

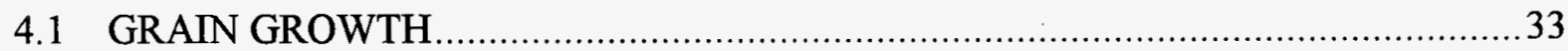

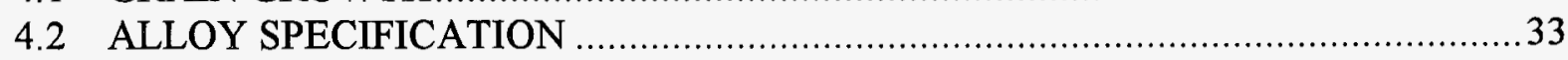

5. LONG-TERM UNIFORM CORROSION OF PASSIVE METALS ……….......................34

5.1 STRUCTURE AND COMPOSITION OF THE PASSIVE FILMS AND

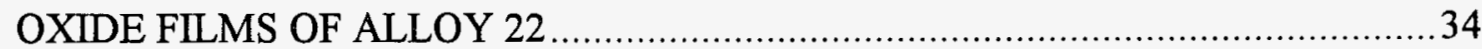

5.2 MODELING OF THE PASSIVE FILM AND THE UNIFORM CORROSION

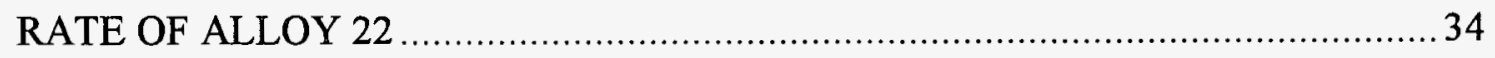

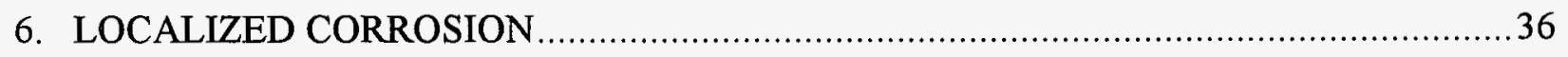

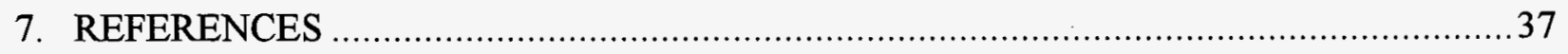

\section{TABLES}

Page

1. Work Scope to Address Waste Package Peer Review Recommendations ............................. 
INTENTIONALLY LEFT BLANK 


\section{ACRONYMS}

ASME American Society of Mechanical Engineers

ASTM American Society for Testing and Materials

BSC Bechtel SAIC Company, LLC

BSW basic saturated water

DOE U.S. Department of Energy

EBS engineered barrier system

GTAW gas tungsten arc welding

LA license application

LLNL Lawrence Livermore National Laboratory

LTCTF Long Term Corrosion Test Facility

SCC stress corrosion cracking

TGA thermogravimetric analyzer

TSPA total system performance assessment 
INTENTIONALLY LEFT BLANK 


\section{MAIN FINDINGS}

\subsection{OVERALL FINDINGS}

Comment 2-1 (pages 6 and 7): The Panel concludes, based on the body of technical information currently available, that Alloy 22 is a suitable material of construction for the outer barrier of a waste package: nevertheless, significant technical issues remain unsettled. ... The Panel concludes that the confidence regarding the long-term performance of Alloy 22 can be substantially increased through further experiments and analyses, and the Panel recommends that this work be undertaken.

Response: The Project agrees that Alloy 22 is a suitable material for the outer barrier of the waste package and that further experiments and analyses can improve confidence in the longterm performance of Alloy 22. The Project believes that the program relies on corrosion data that are widely accepted by the materials research community. While the Project understands that further tests can be performed, the program defined to support the license application (LA) submittal contains the suite of tests necessary to address the areas of greatest importance. Additional testing could make the program more robust, but it will be carried out over a longer time frame and will lead to improved confidence in performance projections. The Project is confident that the testing and analyses to be conducted before submittal of the LA will provide an adequate basis for the LA.

Comment 2-2 (page 7): The Panel concludes that titanium Grade 7 might not be a suitable material of construction for the drip shield. Stress corrosion cracking of titanium Grade 7 has been observed in laboratory tests. If these tests are deemed to have occurred under realistic conditions for the drip shield over waste packages in the repository, then the benefits of titanium are severely diminished. The Panel does not recommend the use of titanium for drip shields, if it is found to be susceptible to stress corrosion cracking under realistic repository conditions.

Response: The Project does not believe that stress corrosion cracking (SCC) is an important issue for the intended performance of the drip shield (i.e., limiting water contacting waste packages and providing protection for waste packages from rock fall).

To evaluate the effects of SCC on the drip shield, staff of the General Electric Corporate Research and Development Center conducted detailed SCC tests of Titanium Grade 7 (Andresen 2001 [DIRS 158600], p. 24). From these studies, it has been concluded that Titanium Grade 7 is resistant to accelerated SCC; however, SCC can potentially occur in Titanium Grade 7 in relevant environments at low growth rates. It is believed that these conditions of stress will only exist at points in the repository where the entire drift collapses or where large rocks fall and impact the drip shield. It is further believed that hot basic saturated water (BSW) will have to exist at the point of impact, further lowering the probability of drip shield failure by SCC. These conditions are not believed to be typical or representative.

Even if SCC could generate through-wall cracks, finite element analysis of bounding residual stress patterns at waste package closure welds and drip shields damaged by rock drops indicate these cracks would be short and tight. For Titanium Grade 7 drip shields, limited length throughwall SCC does not compromise component performance (Andresen et al. 2002 [DIRS 158829]). 
That is, the drip shield would still limit water contacting the waste package and provide substantial protection of the waste packages from rock fall even if SCC were to generate such cracks.

The Project is not alone in concluding that Titanium Grade 7 is a good material for drip shield construction. For example, in a recent TSPA (total system performance assessment), the Electric Power Research Institute (EPRI 2002 [DIRS 158069], p. 1-2) found that the:

DOE [U.S. Department of Energy] has chosen to make the drip shields and containers out of metals that are among the most corrosion-resistant currently available. DOE is conducting tests on the long-term durability of these materials. Data from these tests to date, along with other available data have been used to estimate that these materials will be expected to last, on average, many thousands of years before even the smallest opening through the drip shield or container wall appears.

Titanium Grade 7 remains the reference material for the drip shield at this time. However, it should be noted that alternative concepts are currently being evaluated, providing the option for future changes, if needed.

Comment 2-3 (page 7; see also page 63): Three conditions describe the surfaces of metal that will be subject to corrosion at Yucca Mountain: accumulated dust and particulate on the metal, deposits and scale on the metal, and tight areas of contact (crevices) between metals; moisture must be present for corrosion to occur under any of these conditions. The Panel recommends that a strong technical basis be developed for materials performance under each of these conditions. To help accomplish this, the Panel recommends the formation of a task group of Project technical experts in corrosion, materials science, geochemistry, and hydrology to work together to determine the range of the composition of the environments that could contact waste package surfaces and changes that could occur in the environment on hot metal surfaces and in crevices. The task group should have the authority and responsibility to direct the work.

Response: The Project agrees that it would be useful to improve the understanding of the three potential conditions on the surfaces of the waste packages. The Project has initiated such an effort through integrated testing and thermodynamic modeling. The testing includes ongoing experiments in environmental chambers in which specimens are exposed to elevated temperatures and dripping water. This testing will increase the understanding of the waterchemistry changes, the nature of the scale deposits, and surface degradation. The Project also has conducted, and is continuing, long-term crevice corrosion tests at a variety of conditions in the Long Term Corrosion Test Facility (LTCTF) and in the laboratory using electrochemical potential methods. See responses to Comments 2-17, 3-1, 3-2, 3-13, and 3-16 for discussion of ongoing and planned activities to evaluate the three potential conditions on the surfaces of the waste package.

Thermodynamic modeling is being used to examine plausible environmental extremes (e.g., moist dust, mineral scale, and crevices). Development of the Pitzer database for the EQ3/6 thermodynamic computer code (CRWMS M\&O 1999 [DIRS 153964]) allows modeling of high ionic strength and high-temperature aqueous solutions. Integrated testing and modeling efforts 
guide the Project in that testing provides model parameters and modeling identifies experimental needs. See also the responses to Comments 2-17, 2-27, 3-1, and 3-2.

As suggested by the Panel, the Project will organize an interdisciplinary group to develop and bound the range and composition of environments that could contact waste package surfaces and changes that could occur in the environment on hot metal surfaces and in crevices. The group will include technical managers in the appropriate disciplines who have authority to direct the work.

Comment 2-4 (page 7; see also page 132): Corrosion and mechanical behavior of waste packages must be considered in the selection of design and fabrication methods. The Panel notes a worrisome gap between the design/fabrication effort and the materials/corrosion effort. The former needs to recognize and control the effects of fabrication processes on metallurgical structure and residual stresses, and the latter needs to express findings in useable guidelines to direct design and fabrication decisions. The materials/corrosion work to date has focused on supporting performance assessment. The Panel concludes that it is time to balance this effort with work to support design and fabrication of the waste packages. In particular, work is required on weld and weld repair processes.

Response: The Panel correctly points out that the Project has been focused on conducting the fundamental science necessary to gain an understanding of materials and their properties under corrosion, fabrication, and elevated temperature conditions. The objective of the Project was to understand material behavior in the range of environmental conditions expected in a repository at Yucca Mountain to support development of the technical basis for the site recommendation decision. The Project agrees with the Panel that it is time to apply the fundamental knowledge to development of procurement specifications, including items such as fabrication, welding, and weld repair requirements, which will be analyzed to ensure they meet operational requirements. The Project has made a fundamental commitment to fully integrate activities of the Performance Assessment and Design organizations relative to the waste package. This integration is being accomplished through the managers of the Engineered Systems Project (Performance Assessment) and the Analysis and Component Design Project (Design) and their staff. The Project has planned work to address weld and weld repair processes as discussed in the response to Comment 2-16.

\subsection{CORROSION DEGRADATION MODES}

Comment 2-5 (page 8): Uniform Corrosion: The panel concludes that if the environmental conditions do not cause film-breakdown and localized corrosion, then it is highly likely that the passive film will remain stable and uniform corrosion rates will remain very low. Two phenomena that could jeopardize the desirable long-term behavior are worthy of study: (a) surface segregation of sulfur and (b) transpassive corrosion. Surface segregation of sulfur can occur as a result of thermal treatments (equilibrium segregation) and as a result of uniform corrosion (anodic segregation). Reducing the bulk sulfur concentration of the alloy can minimize both thermal segregation and anodic segregation of sulfur. Transpassive corrosion might be caused by radiolysis of water sitting on the surface of the waste package (a process that the Project states is unlikely to produce transpassive potentials) and/or by a combination of all of the following: low $\mathrm{pH}, \mathrm{Fe}+3$ (from corrosion of steel structures), some amount of radiolysis of 
the water, and an inhomogeneous alloy microstructure (i.e., grain boundary segregated phosphorus, precipitates rich in chromium and molybdenum).

Response: According to the report titled "Interfacial Segregation in Nickel Base Alloys," chromium eliminates sulfur segregation in nickel alloys (Briant 2002 [DIRS 159298]). For example, sulfur segregation was not found to occur in Hastelloy C-276. Since Alloy 22 has significantly more chromium than Hastelloy C-276, thermal segregation of sulfur is not expected. Phosphorous segregation was seen, however, in C-276. The Project has performed calculations for thermal segregation of phosphorous, similar to those presented by the Panel, and has found that thermal segregation is not likely to be a problem under expected repository temperatures. Further, if short-term heat treatment or welding operations were to cause thermal segregation, the degree of segregation would not be likely to change under expected repository temperatures. The Project agrees that the effect of anodic segregation of sulfur on passive film stability must be addressed theoretically, experimentally, or using both methods. The Project also agrees that the effects of sulfur segregation can be eliminated by specifying a lower sulfur concentration if they are found to occur. Thus, an evaluation of sulfur segregation is planned before and after the LA time period. See also the responses to Comments 2-22, 3-7, and 3-8.

The Project agrees with the panel that production of hydrogen peroxide and other products can increase the corrosion potential. However, data obtained by the Project (CRWMS M\&O 2000 [DIRS 153802]) show this effect to be small (less than $200 \mathrm{mV}$ increase in corrosion potential) when hydrogen peroxide was added to the test environment. See also the responses to Comments 2-19 and 3-27.

In addition, the Project has initiated potentiostatic testing over a range of applied potentials and $\mathrm{pH}$ values. Independent determination of critical potential and corrosion potential under these conditions is underway. Some testing aimed at determining the effect of steel engineered barrier system (EBS) component interactions with aqueous solutions on waste package corrosion have also been initiated. Testing in aqueous solutions with ferrous/ferric additions is planned. These tests are mainly intended to support the LA. See also the response to Comments 2-17 and 3-12.

Comment 2-6 (page 8; see also pp. 12, 105, 106, and 107): Localized corrosion: Nickel-base Alloy 22 and titanium Grade 7 are extremely resistant to localized corrosion; they have exhibited no evidence of pitting or crevice corrosion after four years exposures to environments similar to those that may form on waste packages in a Yucca Mountain repository up to $85^{\circ} \mathrm{C}$. Nevertheless, these alloys are susceptible to crevice corrosion under extreme conditions of environment and potential... The Panel recommends a more rigorous approach for determination of the critical potentials. The critical potential should be the repassivation of an intentionally creviced electrode following significant crevice corrosion. The corrosion potential should be modeled and measured under a range of exposure conditions, taking into account the initial surface condition and the effects of high temperature exposure to air. Furthermore, the Panel recommends that the Project perform experiments under conditions beyond those thought to be relevant to Yucca Mountain in order to examine the margins of corrosion resistance.

Response: The Project agrees with the Panel recommendation and is conducting localized corrosion studies under a range of environmental conditions (temperature and water chemistry) to determine the margins of corrosion resistance of Alloy 22. The Project, as discussed below, is 
also further establishing its basis for the corrosion potential and localized corrosion critical potential under a range of environmental conditions. This includes using the TsujkawaHitsamatsu method for determining the repassivation potential of crevice corroding material.

The localized corrosion model used by the Project states that localized corrosion may be expected whenever the free corrosion potential is higher than a given critical potential. This critical potential is the lowest potential that will cause Alloy 22 to corrode irreversibly in a localized manner. The Project does not believe that the critical potential is necessarily the crevice repassivation potential of an intentionally creviced electrode. Measured values of such repassivation potentials (with standard American Society for Testing and Materials (ASTM) methods such as cyclic polarization) depend on the sweep rate and the potential at which the scan is reversed. Such measured values are, therefore, not unambiguous thresholds for localized corrosion. More generally, the Project contends that the critical potential for localized corrosion is the lowest potential under which localized corrosion can be observed in the laboratory. The Project is experimentally determining the corrosion potential, independent of the critical potential, in a variety of environments spanning a broad range of electrolyte composition, $\mathrm{pH}$, and temperature, including conditions beyond those believed to be relevant to Yucca Mountain. The Project has plans to determine the corrosion and critical potentials for base-metal and welded samples representative of actual waste package material, with varying degrees of thermal aging and air oxidation. The Project currently is conducting experiments under conditions that are beyond those thought to bound the Yucca Mountain environment, thereby enabling investigators to establish margins of resistance.

The Panel recommended alternative approaches for determining the critical potential for crevice corrosion; however, the procedure-dependent nature of these proposed methods may pose some difficulty. Furthermore, it is important to note that the proposed methodology has not been adopted as a formal procedure by standing bodies that establish testing standards, such as the ASTM. In contrast, the Project has chosen to use potentiodynamic methods based on ASTM standards. Because of the testing parameter dependence associated with all of the testing methods used to determine critical dependence, the Project will continue to focus on standardized testing procedures. To determine critical potential independent of corrosion potential, however, the project also will use other testing methods, such as the TsujikawaHitsamatsu method recommended by the Panel, for corroborative purposes.

Comment 2-7 (page 9, see also pp. 24 and 124): Stress Corrosion Cracking: The mitigation method, experimental approach, and modeling efforts for stress corrosion cracking are consistent with the state-of-the-art, and appropriate work generally is underway to verify the models... The Panel recommends additional work to address some deficiencies in the current program including improving tests for establishing sensitivity to crack initiation and propagation, replacing the threshold stress component of the slip dissolution model with the threshold stress intensity factor model, and developing constants specific to Alloy 22 for the film rupture/slip dissolution model. The Panel recommends that alternative models for stress corrosion cracking be considered by the Project. Alternative models can provide validation and support for the Project approach. Alternative models also may be required, if the current models are found to be deficient. 
Response: Sensitivity to crack initiation and propagation has been established using fatigued pre-cracked compact tension specimens. Crack length is continuously monitored using high sensitivity reversing direct current potential drop crack growth measurement systems. After SCC is initiated in a given environment under very slow cyclic loading, the load is gently transitioned to a constant value and in some cases, sustained constant load crack growth rates are measured. Constant load growth rates as low as $2 \times 10^{-10} \mathrm{~mm} / \mathrm{s}$ have been readily measured for Alloy 22 in test times less than 500 hours, indicating an incremental crack resolution of about 0.4 microns (Andresen et al. 2002 [DIRS 158829], p. 70). Comparison of post-test destructive examination of crack extension versus on-line measurements indicates agreement within about 20 percent or less. Higher incremental crack growth resolution can be obtained by testing for longer times. See also the responses to Comments 2-24 and 3-17.

Currently, two model approaches for assessing the time to through-wall SCC propagation in the vicinity of the final closure weld are used by the Project. One model is the slip dissolution model coupled with a threshold stress approach, and the other is a threshold stress intensity model. For the former approach, after the threshold stress is exceeded at the outer surface, crack growth is assumed to initiate on a smooth surface or at any surface breaking weld flaws (based on a designated flaw distribution) at a rate related to the calculated flaw/crack tip stress intensity. The crack growth rate is assumed proportional to the stress intensity raised to the power $4 n$, where $n$ is a repassivation rate constant that is material and environment specific. With the latter threshold stress intensity approach, the calculated weld flaw distribution in the vicinity of a weld is evaluated to obtain the flaw(s) with the highest stress intensity, and that value is compared to a threshold value to determine if crack growth will occur. The Project agrees that the application of the threshold stress to preexisting weld flaws is nonconservative and will use threshold stress intensity factors for the welded portions of the waste package containing preexisting flaws in the future. See also the response to Comment 3-18.

The Project also is developing film rupture/slip dissolution model constants specific to Alloy 22 from measurements of crack growth rate versus applied $\mathrm{K}_{\mathrm{I}}$ values in a range of relevant environments. The initially developed $n$ values, described in the Supplemental Science and Performance Assessment (BSC 2001 [DIRS 154657], Section 7.3.3), were represented by a uniform distribution with an upper bound of 0.920 and a lower bound of 0.843 . These values will be compared with values being determined by measurements of the repassivation current decay kinetics (anodic current density versus time) following rapid rupture of the passive film present on Alloy 22 in relevant environments. See also the response to Comment 3-19.

The Project plans to include alternative SCC models in an update to the SCC analysis model report (CRWMS M\&O 2000 [DIRS 151564]), which is under preparation. Predictions using the alternative model(s) will be used to validate and support the Project approach.

See also responses to Comments 2-24, 3-17, 3-18, and 3-19.

Comment 2-8 (page 9): Stress Corrosion Cracking: The Panel recommends that the effectiveness of heat treatment for stress mitigation be thoroughly evaluated by finite-element thermal and stress analysis and by residual stress measurements on prototype containers. 
Response: The Project agrees with the recommendation. The effectiveness of the shop solution heat treatment and the final closure weld local induction annealing stress mitigation treatments have been evaluated by finite element thermal and stress analysis, and the results to date are consistent with residual stress measurements made on waste package processed mock-ups with prototypical closure weld geometries.

Additional measurements and comparisons with model predictions are planned on full-diameter mock-ups. These measurements will be performed on all surfaces of the mock-ups with both lids installed. Additionally, a full-sized prototype waste package is planned for fabrication in the fiscal year 2004 to 2005 timeframe and numerous full scale mock-ups are included in the out years. These prototypes will be subjected to various non-destructive and destructive testing to determine the residual stresses on all of the waste package surfaces. See also responses to Comments 2-23, 3-20, and 3-21.

Comment 2-9 (page 9; see also pp. 25 and 124): Stress Corrosion Cracking: The Panel further recommends that the stress corrosion cracking behavior of Alloy 22 be evaluated with different stages of aging and in environments containing trace impurities, such as lead, that may influence cracking behavior.

Response: Although Alloy 22 is extremely resistant to SCC, the Project has conservatively assumed that SCC is a viable waste package degradation mechanism that could lead to penetration of the Alloy 22 outer barrier by tight cracks in less than 10,000 years. Thus, to preclude SCC, a stress mitigation approach will be used to remove surface tensile residual stress, one of the necessary conditions for SCC to occur. Without a tensile surface stress, it is theoretically impossible to initiate and propagate SCC. As a result, evaluation of the effect of different states of aging on SCC susceptibility does not have a high priority compared to other near-term activities, and the current plan is to assess the aging effect up to and beyond the LA time period (see also responses to Comments 2-21, 3-5, and 3-22). However, with respect to the effects on SCC of trace impurities such as lead, some test results have been obtained, and further testing is underway. In addition, the Project is evaluating the environmental constraints on the solubility of the minor constituents.

\subsection{HIGHER OR LOWER TEMPERATURE OPERATING MODES}

Comment 2-10 (page 10): The Panel concludes that the benefits of moving from the high temperature operating mode, as currently defined, to the low temperature operating mode, are not clearly greater and might be offset by the radiolysis effects, in addition to the burdens of long-term ventilation and increased area for the repository. Work is required for testing and analysis at the higher operating temperatures before final conclusions can be drawn.

Response: The Project agrees that additional testing and analysis are needed before the postclosure thermal condition is selected. Several tests (including localized corrosion, general corrosion, and passive film stability) are underway or are planned at temperatures up to $160^{\circ} \mathrm{C}$, and tests in autoclaves are planned for fiscal year 2003. Tests to better determine the waste package environment are underway and will continue for several years. These tests will include characterization of the possible effects of radiolysis on the environment, that is, the generation of acid gases and oxidizers. The operating-mode decision (including ventilation and repository 
operating area requirements) could be made anytime during the next several years, but this decision is not required before approximately 2010 when fuel receipt and emplacement may begin.

\subsection{ALLOY SPECIFICATION AND COMPOSITION}

Comment 2-11 (page 11; see also p. 74): The Panel recommends that the Project staff determine the effects of alloy composition within the specified ranges of Alloy 22. It is possible that a more restrictive chemical composition specification for given elements would reduce uncertainty and increase confidence with respect to the stability of the alloy and the corrosion behavior of waste packages.

Response: The Project agrees that the effects of alloy composition (within the specified ranges of Alloy 22) on corrosion properties and metallurgical stability are important. A study looking at corrosion properties and metallurgical stability of Alloy 22 weld and base metal (with a wide range of compositions) is currently being initiated. In addition, the Project is planning to look at the effects of different elements on metallurgical stability by varying alloy composition in theoretical models. Because the alloy composition can be specified anytime prior to the fabrication of waste containers, additional heat-to-heat variability studies could be initiated up to and beyond LA, should the results of ongoing testing suggest that compositions not in the current test program be studied.

Comment 2-12 (page 11): ...there will be a strong economic incentive to use less expensive alloys. This should be evaluated most carefully. The Panel recommends that the Project not designate metals less corrosion resistant than Alloy 22 type metals, in view of confidence and uncertainties. Clearly, 304, 316, 825, and others would fail under much more benign conditions than would Alloy 22. It is prudent to use the most corrosion resistant alloy available unless strong, credible evidence is found that a less resistant alloy will work.

Response: The Project agrees with the Panel. The Project will not select metals that are less corrosion resistant than Alloy 22 type metals unless their performance can be demonstrated over the 10,000 -year regulatory period.

Comment 2-13 (page 11; see also page 14): The Panel recommends that a back-up alloy be included in certain of the tests performed on Alloy 22 to address the risks associated with the possibility that, further into the Project, Alloy 22 is found to be inadequate. In addition, the Project should include a comparison alloy, such as 316L stainless steel, Alloy 825, Alloy 600, or Alloy 690, in a greater number of tests than is presently the case. This would provide a means for quantitatively comparing the performance of Alloy 22.

Response: The Project is testing a number of alloys in addition to Alloy 22 . In the Long Term Aging Facility at Lawrence Livermore National Laboratory (LLNL), the Project is testing Alloy 59, another high-nickel alloy with corrosion resistance comparable to Alloy 22, which does not contain tungsten. The Project is also testing materials such as Alloys 625, 825, and C-4 in the LTCTF (Alloy C-4 is expected to be thermodynamically more stable than Alloy 22). These materials could be carried as alternatives to Alloy 22, not because they are superior in performance to Alloy 22, but because they are corrosion-resistant materials that have been used 
widely by industry for many years, and therefore more data exist on their performance. The Project plans to continue to include other corrosion-resistant materials in some of the tests performed on Alloy 22. The Project does not have plans to include a back-up alloy in more tests at this time, but will consider adding a back-up alloy to more tests in the post-LA timeframe.

As recommended, the Project is carrying some comparison materials for testing. By testing standard stainless steels with the Alloy 22, the Project has examples of materials that are subject to various modes of localized corrosion and SCC under expected conditions. The Project has completed tests using 304 and 316L materials (CRWMS M\&O 2000 [DIRS 144229]. There are differences in the resistance of these relatively inexpensive, low-performance alloys and that of Alloy 22. These lesser materials undergo crevice attack and crevice acidification at relatively modest potentials (close to the corrosion potential), whereas Alloy 22 does not. These tests allow for a quantitative comparison with Alloy 22.

\subsection{TECHNICAL ISSUES TO BE RESOLVED}

Comment 2-14 (page 11): The Panel is concerned that adequate resources might not be allocated to complete the work necessary for evaluating the long-term performance of waste package materials. The Panel's perception is that a substantial effort is required to accomplish the needed work to support design and fabrication of durable waste packages. The Panel strongly recommends that adequate resources be provided to substantially build confidence in the long-term performance of waste packages. This area is particularly amenable to progress through experiments and modeling.

Response: The Project agrees with the Panel that confidence in materials performance can be improved through testing and analyses, and that it is important for design and fabrication studies to receive the necessary resources to perform the work. The Project plans to continue testing and analysis to evaluate the long-term performance of waste package materials. Predictions of longterm materials performance will also benefit from information gained through other industrial applications of these materials and materials testing research completed by other organizations. As the Project enters the LA development phase, resources will be allocated to develop the fundamental materials knowledge required for details of design, fabrication, installation, and operation (including the necessary specifications for material fabrication), and to the testing and analytical efforts to demonstrate acceptability of materials performance.

Comment 2-15 (page 11): Design and fabrication procedures: Metallurgical structure, residual stresses, and metal surface condition are all affected by fabrication procedures and, in turn, these conditions can greatly affect corrosion behavior. The Panel recommends a coordinated analysis and testing program between the design/fabrication effort and the materials/corrosion effort. The inclusion of realistic mock-ups and prototypes, in addition to laboratory specimens is expensive, but necessary.

Response: The Project understands and agrees with the Panel about the need for intensive evaluations of fabrication procedures and their impacts on corrosion behavior. The Project agrees that a more comprehensive program will need to be completed prior to spent fuel handling and emplacement in a repository, which will not occur until 2010 on the current schedule. Realistic mock-ups and various prototypical tests are part of the more comprehensive program. 
The Project will need to have a sufficient basis to make the appropriate technical arguments in the LA, but the Project anticipates that there will be several years of additional detailed design and fabrication studies prior to the operational phase of the repository. See also the response to Comment 2-4.

Comment 2-16 (page 12; see also p. 26): Develop and validate weld procedures: The closure weld and its postweld processing are critical to long-term performance of waste packages. The two primary issues regarding long-term integrity of the welds in the Alloy 22 corrosion barrier are the level and nature of residual stresses associated with the closure welds and the stability of the weld metal microstructure. The production and testing of full-scale mockups is required, and a weld repair procedure must be developed and validated.

Response: The Project currently has a program in progress to evaluate the integrity of the Alloy 22 weld and postweld processing. Specific studies are underway that are focused on the level and nature of residual stresses associated with the closure weld and the stability of the weld metal microstructure. The waste package weld flaw analysis program for the LA will be completed in fiscal year 2003. This program is designed to identify and characterize weld flaws. The welding process is cold-wire gas tungsten arc welding (GTAW). This effort includes weld repairs, when necessary. The information gathered from the weld repairs will be used to develop preliminary and eventually final procedures for weld repair.

Another program to analyze the variability in composition of the base metal-weld metal, will begin in fiscal year 2003 and will provide information regarding the mechanical properties of approximately 49 material combinations, all within the American Society of Mechanical Engineers (ASME) composition ranges. Both programs will provide information regarding the resultant postweld microstructures, and samples from these studies will be used for measurements of corrosion resistance and metallurgical stability. The extent of the corrosion testing program and the number of compositions to be studied will be determined using the information gathered on mechanical and metallurgical properties of the welds.

During the evolution of the waste package design, the Project fabricated three mock-ups (full diameter, $1 / 4$ height). The most recent mock-up corresponds to the current design. This fiscal-year-2000 mock-up and the weld procedures are documented in the Waste Package FY-00 Closure Methods Report (CRWMS M\&O 2000 [DIRS 152753]).

Further, a large number of test coupons have been welded using ERNiCrMo-10 filler material. These coupons are being tested and, if a need for additional testing is identified, more coupons may be welded using other alloyed filler material. The filler material variability test scheduled for fiscal year 2003 is intended to determine if the variability in the ASME code materials needs to be tightened to assure a quality weld that meets all requirements.

In fiscal year 2002, the Project will continue the weld integrity studies, which will lead to a weld flaw distribution study. This study will evaluate sixteen ring welds (welds formed in Alloy 22 with a circular configuration to represent the outer lid of the waste package) to assess weld groove configuration followed by nondestructive and metallographic examination to characterize any flaws present. The current Project baseline also includes the design and fabrication of a fullscale prototype scheduled to begin with the procurement of materials in 2003. 
Test programs to evaluate the currently-envisioned postweld processes (laser peening and induction annealing) are being developed and will begin in early fiscal year 2003. Additional testing is planned in the area of low plasticity burnishing as a method to mitigate residual stresses produced by the closure weld and the middle lid. Preliminary indications show that this process may be superior to laser peening. This effort will also include microstructural analyses and measurements of residual stresses on specimens.

The stability of the weld microstructure with temperature is also being evaluated. Precipitation kinetics studies from half-inch thick welds indicate that no significant changes are expected under repository conditions. The Project plans to repeat these studies with prototypical welds in the as-welded condition and with any post-weld processing. There is evidence that solution annealing, for example, will improve the stability of the microstructure. The effect of cold work due to laser peening, burnishing, or both operations is also included in the stress mitigation study for fiscal year 2003 .

Comment 2-17 (page 12; see also page 63): Realistic boundaries for environmental conditions: The determination of the realistic range of aqueous environments on metal surfaces is well underway. The Panel recommends that the Project complete a comprehensive experimental and analytical modeling program to establish the boundaries for three environmental conditions: moist dust, mineral scale and deposits, and crevices. The determination of environment should include temperature, oxidizing potential, $p H$, and composition of ionic species. Work on microbiologically influenced corrosion needs to refocus on the consequences of this corrosionrelated process within the realistic boundaries.

Response: The Project agrees, and continuation of a comprehensive experimental and analytical modeling program aimed at establishing the boundaries for environmental conditions is planned. The experimental and analytical modeling program has made considerable progress in establishing boundaries for plausible environmental conditions. To this end, plausible brines from natural waters have been established. The experimental work on the evaporative concentration of dilute waters (to establish specifics of the end-brine waters) is continuing. These studies assist in establishing the aqueous solution composition and $\mathrm{pH}$. Bounds on electrochemical potential are being characterized in terms of redox couples in the aqueous solutions. The Pitzer database for high ionic strength aqueous solutions at elevated temperatures is expected to be completed during fiscal year 2002. This database is used with the thermodynamic modeling code EQ3/6 (CRWMS M\&O 1999 [DIRS 153964]) to predict properties such as deliquescence point and aqueous solution composition as a function of temperature and relative humidity. Experimental work addressing thin film aqueous corrosion is being conducted with a thermogravimetric analyzer (TGA) and drip testing in an environmental chamber. The TGA studies are being conducted with deposited salts on Alloy 22 under constant temperature and relative humidity. The drip tests are investigating the effect of mineral scale and dust on the corrosion processes. Crevice corrosion is being investigated by conventional electrochemical techniques. Bounding compositions of aqueous solutions due to microbial activity are being characterized, and testing is underway in these environments to establish the effects of microbiologically influenced corrosion. The ongoing testing and modeling efforts are expected to address the Panel comments in this area. See also the response to Comments 3-1 and 3-11. 
Comment 2-18 (page 12): Corrosion behavior within the range of realistic environmental conditions: Project staff should determine the performance boundaries of Alloy 22 in each of the identified corrosion modes: uniform corrosion, localized corrosion, and SCC. The testing should go beyond the range of realistic conditions in order to determine the margins of safety.

Response: Experimental testing (evaporative concentration) and thermodynamic modeling (EQ3/6 with Pitzer database) are being employed to establish bounds in temperature and water chemistry. A considerable amount of corrosion testing (including corrosion weight-loss measurements, electrochemical testing, and SCC over a range of these environments) has been completed. Electrochemical testing and thin film studies are being conducted for environmental conditions outside the expected range. Autoclave tests are planned for fiscal year 2003 at elevated temperatures beyond those possible in aqueous solutions at atmospheric pressure. These tests will be used to evaluate the margins of safety for uniform corrosion, localized corrosion, and SCC. See also the response to Comments 2-17 and 3-3.

Comment 2-19 (page 12; see also p. 86): Radiolysis from gamma radiation: There is no evidence to suggest that radiation damage to the waste package canister material will alter its mechanical properties; therefore, radiation damage studies of alloy 22 are not warranted. In addition, there is no evidence that radiation damage of the passive film will alter its protective properties. However, the production of $\mathrm{H}_{2} \mathrm{O}_{2}$ and other products by radiolysis from gamma rays can result in a positive shift in the open circuit potential and possible degradation of passivity. The Panel recommends experiments and analysis of radiolysis effects at gamma radiation fluxes that will exist when condensed water is present on waste packages.

Response: The Project agrees with the panel that production of hydrogen peroxide and other products can increase the corrosion potential. However, Project data (CRWMS M\&O 2000 [DIRS 153802]) show this effect to be small (less than $200 \mathrm{mV}$ increase in corrosion potential) when hydrogen peroxide was added to the test environment. The Project has also conducted a review of published literature on the aqueous corrosion of various materials including nickel base alloys in the presence of gamma radiation. It has been found that high radiation levels are required to cause enhanced corrosion even in aggressive environments. Alloy C-4, which is less corrosion resistant than Alloy 22, did not show any enhanced corrosion in Q-brines (high ionic strength brines containing magnesium chloride) at radiation levels of $1,000 \mathrm{R} / \mathrm{h}$. This is significantly greater than the radiation levels expected on the surface of the waste package, which has been estimated to be less than $50 \mathrm{R} / \mathrm{h}$ after an emplacement period of 50 years. This time span was selected because no aqueous conditions are expected to be present due to forced ventilation of the drifts during this period. The effects of radiolysis were evaluated and excluded from the TSPA on the basis of low consequence because radiolysis does not initiate localized corrosion or greatly effect general corrosion rates, and therefore has no great effect on dose rate (CRWMS M\&O 2001 [DIRS 153937]). See also the response to Comments 2-5, 3-9, and 3-27.

Comment 2-20 (page 12): Corrosion potential over long periods: Values for the corrosion potential are used in models of corrosion modes. The corrosion potential should be measured over long periods of time in a range of environments with varying chloride concentration, oxyanion concentration, $\mathrm{pH}$, temperature, and radiation. Initial surface conditions must be considered. Theoretical approaches for predicting the corrosion potential over long periods of 
time and the influences of the various environmental parameters should supplement the experimental work.

Response: The Project currently is generating corrosion potential data for a large set of environmental conditions using polished wrought mill annealed Alloy 22 samples. These environments include a range of temperatures in electrolyte solutions such as concentrated calcium chloride to multi-ionic solutions to dilute organic acids. Corrosion potential has been monitored in some of these environments for periods longer than one year, and this work continues. In the near future, Alloy 22 coupons with different surface finish will be added. The Project believes that it is important to run theoretical calculations to predict the influence of chemical species from aqueous solutions on the mixed potential behavior. These calculations will be corroborated with tests to determine the corrosion potential of multi-ionic solutions, one chemical species at a time. See also the response to Comment 2-6.

Comment 2-21 (page 12; see also pp. 18 and 73): Long-term metallurgical stability: Cr-Mo [chromium-molybdenum] depletion and Long Range Ordering: Long term exposure of Alloy 22 to higher temperatures than those expected for the repository can lead to the degradation of corrosion resistance by $\mathrm{Cr}-\mathrm{Mo}$ [chromium-molybdenum] depletion and degradation of mechanical properties by long range ordering. The Panel recommends that Project staff determine whether chromium and molybdenum depletion occurs adjacent to the grain boundaries, and if so the time and temperature relationship for this depletion and its impact on corrosion and stress corrosion cracking. The Panel recommends that long range ordering be given equal importance to that for precipitation because of the implications of ordering for stress corrosion cracking and the potential effects of deformation adjacent to the induction heated and quenched zone accelerating the ordering kinetics.

Response: There is no evidence that $\mathrm{Cr}-\mathrm{Mo}$ depletion prior to precipitation occurs to a large enough extent to cause a degradation of the corrosion resistance. Available data show that the corrosion rate increases monotonically with aging time at temperatures below approximately $760^{\circ} \mathrm{C}$. If depletion causes significant degradation of the properties, then a temporary increase in corrosion rate, for example, would be seen in the early stages of precipitation. See also the response to Comment 3-5.

The Project evaluates long-range ordering with equal importance to the precipitation of tetrahedrally close-packed phases. Theoretical and experimental results show that ordering does not occur under expected repository conditions. Cold work would have to accelerate the ordering by several orders of magnitude before it could occur under the projected repository temperature profile and is, thus, not expected to have an effect. Testing of welded and cold worked samples is currently planned to confirm this conclusion. See also the response to Comment 3-6.

Comment 2-22 (page 13; sce also pages 18 and 73): Effects of sulfur and phosphorus: Sulfur and phosphorus are minor constituents in Alloy 22, and when enriched to high concentrations at grain boundaries and surfaces, they can have detrimental effects on corrosion and stress corrosion cracking resistance. The Panel recommends that Project staff: 1) measure the effects of sulfur on passive film stability in relevant repository environments; 2) model and/or measure the rate of sulfur accumulation on the surface as a function of corrosion rate, if sulfur affects the 
passive film stability; and 3) evaluate the potential for grain boundary impurity segregation as a function of time and temperature in the bulk and weld metal and in the heat affected zone of welds.

Response: Response to Items 1 and 2: The Project agrees that the effect of anodic segregation of sulfur on passive film stability should be addressed theoretically, experimentally, or using both methods. However, as pointed out by the Panel, the effects of sulfur segregation can be eliminated by specifying a lower sulfur concentration in the fabrication process if any effects are found to occur. An evaluation of sulfur segregation is planned up to and beyond the LA time period.

Response to Item 3: Studies of the potential for grain boundary impurity segregation under exposure conditions relevant to the proposed repository have been undertaken in response to recommendations by the Panel. As noted in the response to Comment 2-5, thermal segregation of sulfur is not expected in Alloy 22. Therefore, these studies focused on phosphorous segregation and assumed that the initial phosphorous grain boundary concentration was negligible. The results showed that after a 10,000 -year isothermal treatment at $200^{\circ} \mathrm{C}$, the grain boundary phosphorous concentration was approximately 5.5 weight-percent. Additional studies were conducted using the exposure conditions of a higher-temperature thermal profile that was used in the Supplemental Science Performance Assessment (BSC 2001 [DIRS 154657], Section 5). The grain boundary phosphorous concentration after 10,000 years calculated using this thermal profile was less than 0.07 weight-percent. Thus, under exposure conditions relevant to the proposed repository, grain boundary phosphorous segregation does not pose a threat to waste package performance during the regulatory time period.

Impurity segregation in the heat-affected zone or due to short-term heat treatments is not expected because of the short times involved and because no such segregation has been reported in the literature for these conditions. Therefore short-term heat treatments are not expected to cause impurity segregation sufficient to degrade corrosion properties. No changes to this initial segregation are expected based on the impurity segregation calculations. See also the response to Comments 2-5 and 3-7.

Comment 2-23 (page 13): Effectiveness of tensile stress reduction for mitigating stress corrosion cracking: A principal component of the Project's stress corrosion cracking control strategy is to reduce the tensile stresses on waste package surfaces. Experience from largediameter rolls in paper making machines demonstrates that this is not easily accomplished. There is insufficient experimental data and analytical modeling to support the position that there will be no significant tensile stresses on the waste packages. Experimental and modeling work to support this effort needs to consider the time-temperature constraints during processing to avoid detrimental metallurgical structures on cooling.

Response: The Project recognizes that the annealing of large objects to reduce surface tensile stresses is a challenge. However, results from Project modeling and testing have indicated that, with careful practice, it is possible to achieve the desired level of stress reduction. Analytical modeling has been performed to provide a basis for specifying the shop solution annealing and the site hot cell final closure weld induction annealing process parameters. Target thermal cycles that produce an outer surface compressive residual stress layer of sufficient depth to preclude 
SCC for times greater than the regulatory period, while minimizing the possibility of unacceptable thermal aging induced corrosion degradation, were calculated. Comparisons of residual stress measurements on initial stress mitigation processed Alloy 22 mock-ups with model predictions indicate reasonable agreement between measured and predicted compressive stress layer depths. Additional experimental work is underway or planned to evaluate the corrosion resistance of these thermally processed mock-ups, after installations of the lids. Also, efforts have been initiated to extend the initial mock-up prediction versus measurement results and microstructural and corrosion resistance characterization efforts to stress mitigation processed full diameter "short ring" and 1/4-length mock-ups during fiscal year 2002.

The mock-up is planned to be induction annealed in fiscal year 2003, and measurements will commence shortly there after. The budgets for fiscal years 2002 and 2003 have funds to support this work. Additionally, the Project plans to fabricate a full-sized prototype waste package (with lids installed) in the fiscal year 2004 to 2005 timeframe. This prototype will be subjected to various comprehensive non-destructive and destructive testing, based on these results additional prototypes and testing will be planned in the out-years. See also the responses to Comments $2-8$ and 3-21.

Comment 2-24 (page 13): Stress corrosion crack growth and consequence: Because of the repository's long time frame, the stress corrosion crack growth rates of interest are less than the current experimental detection limits. The Panel recommends further work to demonstrate sufficiently slow crack growth through calibration and validation of stress corrosion cracking models. Stress corrosion cracks cover only a small fraction of a metal surface; they provide a tight, tortuous path through a metal thickness. The Panel recommends an analysis of the likely location, distribution, and geometry of stress corrosion cracks. This will provide useful input to the determination of water ingress through the waste package wall and the eventual egress of radionuclides from the waste package in the event that stress corrosion cracking does occur.

Response: The current crack growth rate measurement sensitivity is discussed in Comment Response 2-7 and 3-17. Crack growth rates measured to date are sufficiently large that once initiated, cracks can potentially grow through-wall in approximately 3,000 years at stress intensity levels that analysis indicates could be present once the mitigated compressive surface layer is removed by corrosion. Detailed finite element model-based analyses using ANSYS (CRWMS M\&O 2001 [DIRS 155753]) have been performed to assess the location, distribution, and geometry of SCCs. Based on these analyses, any through-wall cracks would be very tight and limited in length, thus providing high impedance to water ingress and radionuclide egress from the waste package if stress corrosion were to occur. The high impedance to flow requires radionuclides that may become mobile after contact with liquid water to move through the crack by diffusion, rather than advection. In addition, a detailed weld flaw study to determine the location, distribution, size, and orientation of weld flaws currently is underway. This work is ongoing and will conclude in fiscal year 2003.

Comment 2-25 (page 13): Hydrogen embrittlement of Alloy 22: The nickel-chromiummolybdenum family of alloys is known to be susceptible to hydrogen embrittlement. The degree of susceptibility is a function of alloy composition, cold working, and thermal history among other variables. Hydrogen can result as a by-product of corrosion processes. The Project has discounted hydrogen effects in Alloy 22 based on plans to use the alloy in an annealed condition 
and the known resistance of other nickel-chromium-molybdenum alloys in the annealed condition. The Panel recommends experimental work on Alloy 22 to support this position. While the fabrication strategy is designed to eliminate tensile stresses from the outer surface of the waste packages, industrial experience has shown this to be difficult to achieve completely. It is prudent to determine the affects of tensile stresses that can result from fabrication processes such as quenching and welding.

Response: Damage from hydrogen embrittlement is unlikely because of the high resistance of annealed nickel-chromium-molybdenum alloys (including Alloy 22) to hydrogen embrittlement and because the waste package is solution annealed and thermally processed to produce a compressive residual layer over the entire outer surface. Although not directly generated to provide data on hydrogen embrittlement, some Project data show that Alloy 22 is not susceptible to hydrogen embrittlement. For example, slow strain rate tests performed to high plastic strain levels (high cold-work) in an acidic solution on Alloy 22 specimens polarized to negative cathodic potentials ( $500 \mathrm{mV}$ more negative than the corrosion potential) have shown no evidence of cracking. In contrast, Titanium Grade 12 tested under identical conditions suffered hydrogen induced cracking. Although the Project has not seen any evidence that Alloy 22 is susceptible to hydrogen embrittlement, a limited amount of testing will be completed to confirm this. In view of other higher priority tests, however, this work may not be completed until fiscal year 2004 .

\subsection{ORGANIZATIONAL-MANAGERIAL ISSUES}

Comment 2-26 (page 14): Five fundamental elements make up the waste package design and performance portion of the overall Project: design, engineering, analysis, modeling, and testing. These five fundamental elements are organizationally separated in the current structure. The Panel considers that better integration of these elements is essential.

Response: The Project agrees that better integration is essential. The Project implemented organizational changes in March of this year to improve the integration of Project resources. All environmental, corrosion, and metallurgical testing and modeling, passive film modeling, and model abstraction activities are now managed under a single manager in the Performance Assessment organization. Waste package design and materials fabrication technology are managed under a single manager in the Repository Design organization. Some of the work scope involving welding and stress (previously managed by the Performance Assessment organization) has been moved to the Repository Design organization. The Repository Design organization provides a steady data stream on the efficacy of actual stress mitigation processes to the Performance Assessment organization. Effective integration between these two organizations now exists. Furthermore, the managers of these two organizations hold biweekly meetings that focus on interface and integration issues. The Project also anticipates that the rigor of developing detailed procurement specification and process controls will force additional integration. In addition, the Project has an integrated baselined schedule that depicts activities and information flow between organizations and contractors. Finally, the Performance Assessment and Design Projects are utilizing interface exchange drawings to ensure the appropriate information needed by different organizations is consistent.

Comment 2-27 (page 14; see also p. 63): The Panel has identified two areas that especially require further focus and integration of Project efforts: determination of the realistic range of 
aqueous environments on waste package surfaces and design and fabrication of waste packages for corrosion resistance. For the former, the Panel recommends the direct, collaborative participation of technical experts in corrosion, materials science, geochemistry, and hydrology in work on these conditions. For the latter, the Panel recommends closer integration between the design and fabrication engineers and the corrosion and materials experts working on performance assessment.

Response: The Project understands the concern about the need to better define the realistic range of aqueous environments that can occur on the waste package surfaces. The Project needs to ensure the integration of all current knowledge on this subject and to identify any additional testing that would supplement that knowledge. The recommendation for a multidisciplinary approach is good, and the Project will ensure that the appropriate expertise is focused on this question. The current technical basis predicting long-term performance of materials includes potentially large conservatisms with regard to environmental conditions, and the Project understands that this is an area that would benefit from more realistic environmental bounds. However, this environmental specification may need to remain conservatively represented for the LA because of uncertainty in the chemical species present at any given location in the repository and variability factors that determine the spatial and temporal environmental conditions.

With regard to the concern about the need for better integration between the design and fabrication engineers and the corrosion and materials experts, the process controls that are in place for the LA phase of the program will strengthen these interfaces and improve integration. See also the response to Comments 2-4 and 2-26.

Comment 2-28 (page 14): Increased involvement of technical experts from academia and industry in conceptual work, experimental method development, and analytical procedures could enhance the substance and level of confidence in the technical basis to support evaluation of the long-term performance of materials. Unfortunately, current management and administrative policies and procedures tend to limit broader involvement. A more effective means to engage a broader base of the corrosion science and engineering community in work relevant to the longterm performance of materials at Yucca Mountain would have significant benefits.

Response: The Project has involved and will continue to involve technical experts from academia and industry to enhance the evaluation of the long-term performance of material. The project currently uses experts from various institutions, such as General Electric Corporation, the University of Western Ontario, Pennsylvania State University, and Massachusetts Institute of Technology, to provide technical support and to complete experimental work. The Project expanded the involvement of the corrosion community through this Peer Review Panel and the seventeen subject matter experts supporting the Panel on specific topical areas.

The Project does not believe that the current management and administrative policies and procedures limit broader involvement of technical experts from academia and industry. This Peer review was completed in accordance with a procedure that is consistent with Nuclear Regulatory Commission expectations for peer reviews. This is necessary so that the results of peer reviews will be acceptable in our regulatory environment. 
The Project agrees that the involvement of academia and industry in the conceptual and analytical work would benefit the corrosion work and will continue such involvement in the future. Several technical experts (from industry and academia) in the fields of welding, ASME Code application, and the design, procurement, and fabrication of waste packages have been subcontracted to support waste package design activities. The high-level waste program is also sponsoring a new Science and Technology organization to seek out new ideas and insights from internal and external organizations, which will offer the Project another avenue for using academic and industrial information and expertise.

Comment 2-29 (page 14): The Panel recommends the establishment of an External Advisory Board. Such a Board would be helpful in determining and maintaining focus and direction in the execution of the research agenda of the staff. As mentioned above, the five fundamental elements related to the design and performance of the waste package are organizationally separated at present. An Advisory Board should include both academics and industrial experts with credentials in areas important to the Project and should meet with the staff on a regular basis, perhaps twice a year on-site with interim phone conference updates. We note, moreover, that while the Project staff does include investigators who have important assets and skills, there is no visible senior, visionary leader with a deep materials science and engineering background and management credentials.

Response: At this time, the Project does not plan to establish an External Advisory Board. In this report, BSC is defining specific improvements to experimental and modeling plans that are based on the recommendations of the Panel. BSC has also implemented organizational changes in response to concerns expressed by the Panel (see response to Comment 2-26). The Project has used a range of external review boards in the past and will do so in the future. With the basic design approach now in place, the Project may focus future boards on topical areas where experience from outside the Project is particularly useful. As detailed designs move forward, formal design reviews will include experts who are external to the Project. Similarly, the peer review process uses external independent experts. In addition, it is common for BSC and the teammates to bring offsite personnel to work on specific topics where broader experience is thought to be particularly useful.

With regard to the need for a senior Project Manager with substantial experience in materials science and engineering, the BSC management philosophy relies on providing high quality project managers to support the technical experts and integrate the work activities and products. These managers work with the technical staff to develop high fidelity work plans and schedules so that project management tools, such as critical path evaluations, baselined schedules, and interface exchange drawings, can be used to evaluate progress. In this manner, the overall progress of all aspects of the engineering and scientific programs can be evaluated, and interface and integration issues can be recognized and addressed. In addition, BSC has organized a Project Oversight Board to provide technical oversight for the overall program of testing, analysis, and modeling. 


\section{SUMMARY OF DEGRADATION MODES AND CONTRIBUTING FACTORS}

\subsection{COMPOSITION OF AQUEOUS ENVIRONMENTS}

Comment 3-1 (page 17; see also pp. 55, 58, and 60): Expand the current work on understanding the effects of the interactions between seepage waters and hot (greater than $100^{\circ} \mathrm{C}$ ) metal surfaces on both the solution composition and the corrosion of engineered materials. The goal is to provide information on both the nature of the deposits that form and the type and rate of corrosion underneath the deposits. Experiments at high temperatures should have higher priority than lower temperature (less than $100^{\circ} \mathrm{C}$ ) studies. The Panel notes that Project staff has recently begun experimental work in this area and we support and encourage this new direction.

Response: As noted by the Panel, the Project is studying the effects of interactions between thin aqueous solutions and hot (greater than $100^{\circ} \mathrm{C}$ ) metal surfaces to gain an understanding of waterchemistry changes and the nature of the surface degradation and scale deposits. Particular emphasis is being placed on the effects of thin aqueous films on the corrosion processes. To understand these effects, the Project is conducting tests at elevated temperatures under constant relative humidity with a TGA and in environmental chambers. The environmental chamber work includes studies on metal-thin film aqueous solutions and metal-dripping water interactions. Surface analytical techniques such as optical microscopy, Raman microscopy, microprobe, and scanning electron microscopy may be employed. Corrosion products may also be analyzed by wet chemical techniques such as ion chromatography and inductively coupled plasma spectroscopy. High-temperature studies are the focus of the thin film studies with a TGA and drip tests in the environmental chamber. Low-temperature studies may be performed to obtain additional understanding of corrosion process kinetics and mechanisms. See also the response to Comments $2-17$ and 3-11.

Comment 3-2 (page 17; see also pp. 51, 60, and 63): Continue to focus on developing a technical basis for environmental extremes that are realistic for each of the three surface scenarios (moist dust, scale, and crevices). These analyses must also include a delineation of the inherent uncertainties, such as the relative importance of transient vs. steady state environments.

Response: Thermodynamic modeling combined with experimental testing is continuing the development of the technical basis for plausible environmental extremes, which include moist dust, mineral scale, and crevices. The development of the Pitzer database for the EQ3/6 thermodynamic computer code, which allows modeling of high ionic strength and hightemperature aqueous solutions, is one part of this effort. Calculation of Pourbaix (Eh-pH) diagrams aids in identifying solution compositions where environmental extremes may be worth investigating. Experimental work discussed elsewhere, including electrochemical and thermogravimetric, will aid in model development.

Water drip tests on Alloy 22 are useful for examining transient environments, while thin film corrosion studies with hygroscopic salt are useful for examining "steady state" environments. See also the response to Comments 3-1 and 2-17. 
Comment 3-3 (page 17; see also p. 61): Improve coupling between thermal-hydro-chemical, engineered barrier system, and environment calculations and the experimental results. Data needed for the environment on the waste packages must drive the nature of the computational and experimentation thermal hydrology work in the unsaturated zone.

Response: A team of technical staff from the relevant technical disciplines has been formed to establish the environment on the waste packages. EBS personnel, along with Unsaturated Zone department personnel and the U.S. Geological Survey, are establishing sources and quantities of hygroscopic salts. Thermal-hydrologic modeling by the EBS personnel establishes the temperature and relative humidity conditions for the waste packages. Personnel from the EBS and Waste Package departments are developing a Pitzer database to be used with the thermodynamic code (EQ3/6) to model high ionic strength aqueous solution at elevated temperatures. See also the response to Comments 2-17 and 3-2.

Comment 3-4 (page 17; see also pp. 55, 61, 62, 63, and 85): Shift the focus in the study of microbiologically influenced corrosion. It is unlikely that the Project will be able to demonstrate unambiguously that microbes are not viable under expected repository conditions. Instead, the Project should characterize the possible metabolites and the effects of these on the engineered materials, including any steel components used in the repository.

Response: The Project has a good basis to expect that microbiologic activity will be limited under certain temperature and relative humidity conditions, particularly at high temperatures and low relative humidities. However, the viability of microbes will still be included in waste package corrosion modeling. In addition to the direct studies of biofilms on Alloy 22, the Project is conducting testing with metabolites of microbial activity. For instance, testing is being performed in organic acids, such as oxalic acid. Microbial metabolites from microbiologicallyinfluenced corrosion of ground support materials, mild steel, and concrete are considered in the corrosion of Alloy 22.

Determining the effects of microbes on the localized performance bounds of Alloy 22 is the emphasis of the microbiologically-influenced corrosion studies. The Project is investigating the effect of microbes on localized corrosion with polished and welded specimens. Other less corrosion resistant alloys show enhanced susceptibility in weld regions. The polished specimens will allow characterization of the corrosion degradation on a microscopic level. The Project is performing localized corrosion testing with microbes on highly polished specimens to characterize the surface degradation. An effort will be made to characterize the biofilm chemistry, but the identification of the biofilm chemistry is difficult because of the complicated nature of the microbial community within the biofilm.

\subsection{METALLURGICAL STABILITY}

Comment 3-5 (page 18; see also pp. 71 and 72): Determine whether chromium and molybdenum depletion occurs adjacent to the grain boundaries and, if so, determine the time and temperature relationship for this depletion and the impact of this depletion on corrosion and stress corrosion cracking. 
Response: The Project has aged, and continues to age, thousands of Alloy 22 samples using a wide range of times and temperatures. Many of these samples were designated for corrosion testing. Thus, any degradation of the corrosion rate in the early stages of precipitation due to chromium-molybdenum depletion or any other mechanism should be apparent. Although the Project currently has data only for "fully" aged material (aged to produce grain boundaries completely covered by tetrahedrally closed-packed phases), there are literature data available for corrosion properties measured in environments designed to promote grain boundary attack of Alloy 22 aged for a range of times and temperatures. None of these data show accelerated attack in the early stages of precipitation, and the corrosion (and mechanical) properties show a monotonic degradation with aging time at all temperatures. Thus, the Project believes that the "fully" aged material is bounding. Should further testing indicate that the earlier stages of precipitation cause a greater degree of property degradation than the later stages, the mechanism of that degradation would be evaluated. See also the response to Comments 2-21 and 3-19.

Comment 3-6 (page 18; see also pp. 72 and 85): Give long-range ordering importance equal to that given to precipitation because of the implications of ordering for stress corrosion cracking, hydrogen embrittlement, and the potential effects of deformation adjacent to the induction-heated and quenched zone accelerating the ordering kinetics.

Response: The Project does evaluate long-range ordering with equal importance to the precipitation of tetrahedrally close-packed phases. Over half of the samples in the long-term aging facility have been or are being aged at temperatures where this ordering occurs. SCC tests have been done on Alloy 22 samples aged to produce long-range ordering, and more tests are planned. For hydrogen embrittlement, see the response to Comment 3-23. Experimental characterization and theoretical modeling of long-range ordering has shown that ordering will not occur in Alloy 22 at expected repository temperatures. Although cold work can accelerate aging kinetics, it would have to accelerate long-range ordering by several orders of magnitude before ordering could occur under repository conditions. Thus, although the effect of cold work on aging kinetics is currently planned, no degradation at repository-relevant temperatures is expected. See also the response to Comment 2-21.

\subsection{LONG TERM UNIFORM CORROSION}

Comment 3-7 (page 20; see also pp. 84 and 86): Surface segregation of sulfur and transpassivity are the two most likely factors that would cause significant rates of uniform corrosion of Alloy 22. Therefore, changes in the structure and composition of the passive film as a function of surface segregation of sulfur and as a consequence of highly oxidizing potentials should be investigated.

Response: The Project agrees with the Panel that if enough sulfur is accumulated on the metal oxide interface, this could hinder the protectiveness of the passive oxide film and probably cause higher corrosion rates for a short period of time. As discussed in the responses to Comments 2-5 and $2-22$, the temperature profiles projected for the repository do not cause significant thermal segregation of impurities. The Project agrees that anodic segregation should be addressed theoretically, experimentally, or using both methods. However, because the detrimental effects of sulfur segregation can be eliminated by a reduction of the sulfur in the alloy, this work can 
continue beyond LA with studies designed to produce a detailed specification of Alloy 22 compositional ranges.

Similarly, the Project agrees with the Panel that if the applied potential is higher than the transpassive potential, relatively high general corrosion rates may be induced on the alloy. However, in all the environmental conditions tested to date, Alloy 22 shows a margin of potential higher than $300 \mathrm{mV}$ between the corrosion potential and the transpassive potential. Therefore, it is unlikely that a natural redox potential will raise the mixed potential to values high enough to produce transpassivity. In addition, if by chance this transpassive potential is achieved, the natural reduction reaction at the cathodic sites will not be strong enough to sustain a high anodic current of transpassive dissolution of Alloy 22. Testing is continuing to confirm these assumptions.

Comment 3-8 (page 20): The Panel recommends that two causes of surface segregation of sulfur be investigated: equilibrium segregation due to high temperature heat treatments and anodic segregation resulting from uniform corrosion of Alloy 22. The Panel recommends the determination of critical bulk sulfur concentrations below which heat treatments and anodic segregation do not cause significant increases in the uniform corrosion rate of Alloy 22.

Response: See the response to Comments 2-5 and 3-7.

Comment 3-9 (page 20): Determination of the likelihood of radiolysis of the water causing transpassive dissolution of fully homogenized Alloy 22. This should be done for the range of solution compositions relevant to the repository at Yucca Mountain and in particular, the full range of solution $\mathrm{pH}$ should be investigated.

Response: Data obtained by the Project (CRWMS M\&O 2000 [DIRS 153802]) show that the effect of radiolysis on the corrosion potential of Alloy 22 is small (less than $200 \mathrm{mV}$ increase in corrosion potential) when hydrogen peroxide at saturation levels was added to the test environment. The Project has also conducted a review of published literature on the aqueous corrosion of various materials (including nickel based-alloys) in the presence of gamma radiation. It has been found that radiation levels much higher than those expected at Yucca Mountain are required to cause enhanced corrosion even in aggressive environments. As noted in Comment 2-19, this process was evaluated and excluded from TSPA on the basis of low consequence. See also the response to Comments 2-5 and 3-27.

Comment 3-10 (page 21; see also p. 84): The Panel recommends that changes in structure/composition of the high temperature oxide films as a result of immersion in the various solutions relevant to the repository at Yucca Mountain be investigated. Changes in the films need to be investigated at a range of potentials and temperatures. Such experiments have been proposed by the Project and some work is already underway.

Response: The Project agrees with the Panel that it is important to determine the evolution of the high-temperature formed oxide film while immersed under different environmental conditions (electrolyte composition, $\mathrm{pH}$, temperature, and applied electrochemical potential). These types of experiments are currently planned and some of this work will be completed prior to submitting the LA. 
Comment 3-11 (page 21; see also p. 85): The Panel recommends testing the uniform corrosion rate of coupons in the Long Term Corrosion Test Facility at temperatures higher than the present maximum of $90^{\circ} \mathrm{C}$. Higher test temperatures are warranted (1) by the increase in oxidation rate of Alloy 22 with increasing temperature, which was observed in short duration electrochemical tests, and (2) by the knowledge that salts with deliquescence points of $\sim 25 \%$ $R H$, might contact the surface of the waste package. The presence of salts with low deliquescence points would place the waste package in contact with an aqueous phase at temperatures as high as $\sim 160^{\circ} \mathrm{C}$, albeit for a relatively short period of time.

Response: The Project agrees that testing at temperatures higher than $90^{\circ} \mathrm{C}$ is warranted. A key concern is for temperatures and relative humidities at which salt deposits could deliquesce. The Project is currently assessing the likelihood of salt deposits deliquescing at high temperatures.

By the end of fiscal year 2002, the Project will have data that measure container material corrosion across the expected range of temperatures under which aqueous corrosion conditions are anticipated. These tests have been completed at $60^{\circ}$ and $90^{\circ} \mathrm{C}$ in the LTCTF. The corrosion rates measured after two years do not show any discernible effects of temperature or environment (CRWMS M\&O 2000 [DIRS 153802]). However, this temperature range does not cover the entire range over which aqueous conditions may be present at the Yucca Mountain repository. More recently, these tests have been augmented with shorter-term electrochemical tests at temperatures up to $150^{\circ} \mathrm{C}$.

To account for corrosion rates at temperatures above $120^{\circ} \mathrm{C}$, the Project has reviewed the available short-term data (other than LTCTF data) and has developed correlations for temperature dependence. These data suggest weak temperature dependence for the range of interest with activation energies in the range of about $25 \mathrm{~kJ} / \mathrm{mol}$. Such a weak dependence is expected for a highly corrosion resistant material such as Alloy 22 .

The Project plans to test immersion coupons (plain, creviced, and stressed) in the LTCTF at temperatures as high as $120^{\circ} \mathrm{C}$ and in more aggressive solutions than currently used. Due to material limitations and safety concerns, $120^{\circ} \mathrm{C}$ is the highest temperature that can be used under ambient pressure conditions in the LTCTF.

Another concern associated with temperatures higher than the LTCTF test temperatures is the possibility of localized corrosion causing a higher effective corrosion rate than occurs with general corrosion for which LTCTF data are representative. However, corrosion potential measurements carried out by the Center for Nuclear Waste Regulatory Analysis suggest that corrosion potentials do not exceed repassivation potentials, even at temperatures as high as $150^{\circ} \mathrm{C}$ (Sridhar 2001 [DIRS 159201]). These experiments were conducted in an environment (silica-free, chloride only without the presence of other corrosion inhibiting anions) that is more aggressive than the expected environment in the Yucca Mountain repository. The results are consistent with the Project assumption that the corrosion rates measured in the LTCTF can be extrapolated to higher temperatures, with reasonable confidence that localized corrosion will not occur.

Under projected repository conditions, aqueous solutions at elevated temperatures (greater than $120^{\circ} \mathrm{C}$ ) could occur if chloride salts of calcium $\left(\mathrm{CaCl}_{2}\right)$ or magnesium $\left(\mathrm{MgCl}_{2}\right)$ are present. To 
evaluate the effect of these hygroscopic salts, atmospheric corrosion studies (i.e., aqueous, thin film studies) with deposited $\mathrm{CaCl}_{2}$ are being conducted at temperatures up to $160^{\circ} \mathrm{C}$ using a TGA and an environmental chamber. The Project is also addressing the likelihood of $\mathrm{CaCl}_{2}$ and $\mathrm{MgCl}_{2}$ deposition on the waste packages and the quantities that could be expected. Thermodynamic modeling is also underway to understand the compositions of aqueous solutions that could develop under the projected temperature and relative humidity conditions. See also the response to Comments 2-17 and 3-1.

Comment 3-12 (page 21; see also pp. 23, 86, and 107): The Panel recommends testing the uniform corrosion rate of Alloy 22 at high passive potentials for long periods of time. Short time electrochemical tests indicate the uniform corrosion rate of Alloy 22 increases with applied passive potential. High corrosion potentials might be established on waste canisters of Alloy 22 as a result of the combined effects of $\mathrm{Fe}^{+3}$ corrosion products from steel structures in the vicinity of the waste package and radiolysis of the water on the surface of the waste package.

Response: The Project understands the benefits of testing the behavior of Alloy 22 at high applied potentials to simulate, for example, the presence of ferric ions in the system. The Project has initiated some limited experimental testing aimed at determining the interaction of steel ground support components with aqueous solutions on waste package corrosion. The Project has commenced constant potential tests in the laboratory that are expected to continue for long periods of time. Potentiostatic testing with a range of applied potentials is underway and potentiostatic testing at high applied potentials are planned. In addition, the Project is evaluating plausible environmental extremes under repository conditions. Testing in aqueous solutions with ferrous or ferric additions is planned. See also the response to Comments 2-5, 2-21, 3-9, and 3-27.

\subsection{LOCALIZED CORROSION}

Comment 3-13 (page 22; see also p. 106): Undertake studies of localized corrosion propagation and arrest to supplement work on initiation because these factors will control the accumulated extent of damage from localized corrosion should it occur. Experiments in aggressive environments provide the opportunity to study growth and arrest behavior. Since there is a chance that the waste package surface will be exposed only to a moist dust environment rather than to dripping or full immersion, the possible influence of such an exterior environment on limiting localized corrosion growth should be studied.

Response: In the current localized corrosion degradation model, the Project conservatively assumes that if localized corrosion is initiated, it would continue at the same high constant rate indefinitely. The Project understands that this is a gross overestimation and concurs with the Panel that studies of localized corrosion stifling should be undertaken. Also, the Project understands that it is unlikely that the waste package will be able to sustain conditions needed for the localized attack at a constant rate for long periods of time. The Project concurs with the Panel that studies of localized corrosion in presence of thin films should be undertaken to determine the environmental conditions for nucleation, propagation, and arrest. Thin-film solution experiments, aimed at investigating arrest mechanisms, are currently underway. Modeling of localized corrosion arrest has been done by the Project in the past. Refinement of this model is planned. See also the response to Comment 3-16. 
Comment 3-14 (page 22; see also p. 106): Examine the effects of metal surface condition on localized corrosion. The metal surface condition can have a large influence on the localized corrosion behavior. In general, the susceptibility to localized corrosion increases as the roughness of the surface finish increases. On the other hand, protective surface films can reduce the likelihood for localized corrosion.

Response: The Project agrees with the Panel that the influence of surface conditions on the susceptibility of Alloy 22 to localized corrosion should be examined. Experiments for evaluating this effect are planned and can continue beyond LA because the surface condition can be tailored as part of waste package fabrication.

To reduce the potential for localized corrosion due to the surface finish roughness, the Project has developed surface finish design criteria for the waste package. In September 2001, the Project published the Waste Package Operations Fabrication Process Report (Plinski 2001 [DIRS 156800], Section 4.1, third paragraph), which states "The disposal container/waste package, excluding the label, shall have an external surface finish Roughness Average of $250 \mu$ in $(6.36 \mu \mathrm{m})$ or less."

Comment 3-15 (page 23; see also p. 106): Address the influence of structural changes on the susceptibility to localized corrosion. The structure of Alloy 22 might change during long-term aging at moderate temperatures; it will certainly change locally as a result of the multipass weld required to seal the canister. The Panel recommends that experiments for determination of $E_{R, C R E V}$ described above be performed on welded samples.

Response: The Project has corrosion data on thin welded samples. To date, no accelerated or localized corrosion effects have been seen. General and localized corrosion experiments (aimed at determining $\left.E_{R, C R E V}\right)$ of thicker multipass welds are underway.

Comment 3-16 (page 23; see also p. 108): Examine localized corrosion behavior for the most relevant conditions that can result in wet environments in contact with metal surfaces: moist dust surface associated with humid air exposure or scale and deposits formed by evaporated drips. Full immersion of metal surfaces is a highly unlikely condition in the repository. It is unlikely that the thin aqueous layer on a waste package will be able to support the cathodic reactions needed to maintain localized corrosion to the same extent as possible in bulk solutions. This has not been addressed by anyone in the field of localized corrosion. The Panel recommends that the Project complete analysis of the initiation, propagation, and arrest of crevice corrosion and pitting under the conditions listed above.

Response: BSC agrees with the Panel that issues of nucleation, propagation, and arrest of localized corrosion under conditions of limited accessibility of electrolyte solution and limited cathodic reactions should be fully investigated. The current Project model is conservative in the sense that it assumes a constant propagation rate of localized corrosion nourished with an endless supply of electron getters and the permanent presence of a conductive electrolyte. Modeling of localized corrosion arrest has been done by the Project in the past and model refinements are planned. Experimentally, the Project is investigating the cathodic reaction influence and the effects of acid gas volatility on localized corrosion. 
At present, the project is investigating the extent to which a limited amount of deposited salt in a thin aqueous film can cause corrosion. These studies are being conducted (fiscal year 2002) using a TGA under conditions of constant temperature $\left(100^{\circ} \mathrm{C}\right)$ and relative humidity. Surface analytical techniques will be employed to characterize the surface degradation. Electrochemical studies exploring thin film corrosion are planned for fiscal year 2003.

The Project is investigating the possibility of electrochemical corrosion inhibition due to precipitation of insoluble minerals at cathodic sites where $\mathrm{pH}$ is elevated due to oxygen reduction. The Project is employing surface analytical techniques to investigate evidence of this mineral precipitation on the post-test TGA specimens. The Project is also investigating this scenario by modeling the Eh- $\mathrm{pH}$ dependence of possible corrosion products. Results will be presented in terms of Pourbaix (Eh-pH) diagrams. See also the response to Comment 3-13 for a discussion of the Project effort on propagation and arrest of localized corrosion.

\subsection{STRESS CORROSION CRACKING}

Comment 3-17 (page 23; see also p. 123): The Project staff has proposed two stress corrosion cracking models: an initiation model based on a threshold stress intensity factor and a propagation model based on film rupture/slip dissolution. Sensitivity of the crack growth measurement techniques is a critical issue for experiments designed to verify both of the models. In the current experimental procedures used by the Project staff, the sensitivity to crack growth has not been established and appears to be inadequate. The Panel recommends that the maximum sensitivity to crack growth in the threshold stress intensity factor and crack propagation tests be established and improved. If necessary, a combination of accelerated testing, longer exposure periods, and fractography could be used.

Response: Sensitivity to crack initiation and propagation has been established using fatigued pre-cracked compact tension specimens with crack length continuously monitored using high sensitivity reversing direct current potential drop crack growth measurement systems. After SCC has initiated in a given environment under very slow cyclic loading, the load is gently transitioned to a constant value and in some cases, sustained constant load crack growth rates are measured. Constant load growth rates as low as $2 \times 10^{-10} \mathrm{~mm} / \mathrm{s}$ have been measured for Alloy 22 in test times less than 500 hours, indicating an incremental crack resolution of about 0.4 microns (Andresen et al. 2002 [DIRS 158829], p. 70). Comparison of post-test destructive examination of crack extension by fractography, for example, versus on-line measurements indicates agreement within about 20 percent or less. Still higher incremental crack growth resolution can be obtained by testing for longer times. See also the response to Comments 2-7 and 2-24.

Comment 3-18 (page 24; see also p. 123): In the film rupture/slip dissolution model, crack propagation is assumed to occur above a threshold stress. The threshold stress criterion used in the model is not conservative. Threshold stresses for the initiation of cracking on surfaces containing defects are generally much lower than those of smooth surfaces on which the threshold values used in the model are based. The Panel recommends that the threshold stress component of the slip dissolution model be replaced with the threshold stress intensity factor model for the welded portions of the waste package which will contain preexisting flaws. 
Response: The Project agrees with the Panel that the threshold stress component of the film rupture/slip dissolution model is sensitive to the presence and size distribution of pre-existing flaws that may be present at welds. The finite element model calculations for the compressive surface layer thickness present over the waste package outer surfaces varies from a minimum depth of about $6 \mathrm{~mm}$ in one region of the final closure weld to at least $10 \mathrm{~mm}$ over the balance of the outer surfaces. Thus, initially, any surface-breaking flaw must be at least $6 \mathrm{~mm}$ deep in the region of the outer final closure weld and at least $10 \mathrm{~mm}$ deep away from the final closure weld region before the flaw tip has the potential to lie within a tensile stress field, a necessary conditions for crack initiation and growth. Based on an assessment of the most likely weld flaw distribution, the probability of having a final closure weld flaw of at least $6 \mathrm{~mm}$ is less than about $1 \times 10^{-6}$ per closure weld (CRWMS M\&O 2000 [DIRS 152097], p III-7). The Project has used threshold stress and threshold stress intensity models and agrees that application of the threshold stress to preexisting flaws is nonconservative. Threshold stress intensity factors will be used for the welded portions of the waste package that contain preexisting flaws.

SCC tests on smooth specimens with machined surfaces representative of the expected surface finish range on the waste package closure weld region (72-250 roughness average) have been evaluated, and tests continue on specimens with a surface finish roughness average of about $135 \mu \mathrm{in}(3.43 \mu \mathrm{m})$. In addition, constant load tests are underway using notched (0.010-inch notch root radius, stress concentration factor of about 3) uniaxial Alloy 22 tensile specimens tested under constant load in $105^{\circ} \mathrm{C}, 20$ percent $\mathrm{BSW}$ brine solution at over-yield stress levels. See also the response to Comment 2-7.

Comment 3-19 (page 24; see also p. 123): The calculations of the constants in the film rupture/slip dissolution model for Alloy 22 are based on relationships developed for 304 stainless steel in $288^{\circ} \mathrm{C}$ water. It is likely that these constants are not applicable because of differences in the deformation behavior between 304 stainless steel and Alloy 22. The Panel recommends that Project staff develop constants specific to Alloy 22 for the film rupture/slip dissolution model.

Response: The Project agrees with this comment. Initial specific Alloy 22 film rupture/slip dissolution model constants have been developed and are described in the Supplemental Science and Performance Assessment (BSC 2001 [DIRS 154657], Section 7.3.3) treatment of repassivation rate (see also the response to Comment 2-7 for additional details). These Alloy-22 parameters lead to slower crack growth rates than do the stainless steel parameter values that were used previously. See also the response to Comment 2-7.

Comment 3-20 (page 24; see also p. 124): The Project plans to reduce residual tensile stresses in the waste package to mitigate the initiation of stress corrosion cracking by means of a stress anneal and water quench of the entire Alloy 22 waste canister, followed by an induction anneal or laser peening of the final closure welds. Based on experience with suction roll shells in the pulp and paper industry, the quenching process after solution annealing could produce unacceptably high tensile residual stresses. On the other hand, slow cooling could lead to the initiation and growth of deleterious grain boundary precipitates. The Panel recommends that the issue of heat treatment for stress mitigation and alloy stability be thoroughly evaluated. 
Response: The Project agrees with the Panel and plans to theoretically and experimentally evaluate the effects of stress mitigation heat treatments on alloy stability. See also the response to Comment 3-21.

Comment 3-21 (page 24): Two approaches can be employed to minimize tensile residual stresses induced by cooling after solution annealing. The first is to cool the fabricated containers slowly. This approach may require the use of an alternative nickel base alloy (to Alloy 22) that is not susceptible to sensitization during the slow cooling process. The second is to carefully design and control the quenching process so that minimal levels of tensile residual stress are produced at or near free surfaces during the quenching operation. The selected approach should be verified by finite-element thermal and stress analysis and by experimental measurements on prototype containers.

Response: The Project agrees with the Panel and plans to carefully control the quenching process to produce a compressive stress layer without unacceptable sensitization in the regions of the waste package containment boundary surfaces of sufficient depth to provide high confidence that the target regulatory lifetime is attained. The selected approaches have been evaluated by finite element thermal and residual stress analyses, and also by experimental residual stress measurements on thermally processed waste package mock-ups. The project plans to evaluate the process effectiveness on the full diameter, 1/4-length waste package prototype mock-up with lids installed. This mock-up (without the closure lid) was solution annealed at Nooter Corporation. Prior to the execution of this process, a finite element model was developed to predict the stress distribution and the parameters for the annealing. Project materials and corrosion specialists were consulted to develop the best ramp-up and cool-down parameters. These specialists also witnessed the annealing process.

The induction annealing process is being performed with input from a panel of experts in materials and corrosion. Finite element models have been developed to predict stress distributions and to establish parameters for the test. Stress mitigation techniques are being studied in continuing consultation with the materials and corrosion experts. When these tests are completed, thorough testing of residual stress and other properties will be conducted on surfaces of the mock-up.

In addition to testing the mock-up to see if compressive stress is present on all external areas of the outer barrier, the Project plans additional checks to assure that compressive stress is present. In fiscal year 2004, the Project plans to fabricate a prototype vessel. During fabrication, a coupon would be attached or an area of excess material would be tested on each piece that is annealed. The Project will test the prototype vessel to assure that the outer barrier is indeed in compression. The Project will also send the coupons to an independent laboratory for testing to verify all properties, including compressive stress, after the annealing operation. This is consistent with the fabrication and annealing of Navy generators.

See also the responses to Comments 2-8 and 2-15.

Comment 3-22 (page 25; see also p. 124): The Panel recommends that the effects of early stages of ordering, grain boundary segregation, and impurity segregation on stress corrosion cracking be evaluated. These processes may be dependent on the composition of the alloy, so the 
Project staff should evaluate the role of heat-to-heat variation on stress corrosion cracking behavior for the different stages of aging.

Response: The Project agrees that evaluation of early stages of ordering, grain boundary segregation, and impurity segregation, as well as heat-to-heat variations is important. Efforts are underway to perform this evaluation with respect to mechanical property changes and potential changes in general and localized corrosion resistance. However, in the case of SCC resistance, the Project approach is to preclude SCC through residual stress mitigation processes that remove the near surface tensile stresses that are required for SCC to occur regardless of materials susceptibility. As a result, the Project has not placed a high priority on evaluating the effect of different states of aging on SCC susceptibility, and the current plan is to assess the effects of aging up to and beyond the LA time period. See also the response to Comments for 2-9, 2-21, and 3-5 for early ordering and precipitation stages, Comments 2-5, 2-22, 3-7, and 3-8 for impurity segregation, and Comment 2-11 for heat-to-heat variability.

\subsection{HYDROGEN EFFECTS}

Comment 3-23 (page 25): The Panel recommends that experimental work be undertaken to explore the hydrogen embrittlement susceptibility of cold worked and cold worked and aged Alloy 22 in repository environments to simulate service conditions associated with residual stresses derived from welding and fabrication.

Response: The Project agrees with the Panel and is evaluating hydrogen embrittlement susceptibility of Alloy 22. See also the response to Comment 2-25.

\subsection{FABRICATION OF WASTE PACKAGES}

Comment 3-24 (page 26; see also page 134): Carry out a weld filler metal qualification program. The ERNiCrMo-10 filler metal has been used in the early development studies because it is the matching composition to the Alloy 22 base metal. It is likely that better longterm performance can be achieved by the use of an alternate filler metal. The effect of postweld annealing on the weld microstructure is not clear, nor is the long-term stability of the weld metal relative to long range ordering.

Response: The base metal-weld metal composition variability test, which will be conducted in fiscal year 2003, will produce mechanical, corrosion, and metallurgical properties of differing weld filler material compositions. This is the first step in a weld filler metal qualification program that will continue beyond LA. As appropriate, samples from this testing will be subjected to long-term corrosion investigations. See also the response to Comment 2-16.

Comment 3-25 (page 26; see also page 135): Evaluate alternate welding processes for the closure weld. While the GTAW process is reliable and dependable, it is slow and results in high levels of residual stress. Electron beam welding is attractive because it eliminates the need for a weld joint and can be conducted in a single pass, thus reducing the weld time significantly. $A$ "single shot" process such as friction welding is also very attractive from both a metallurgical, residual stress, and productivity standpoint. Because friction welding is a solid-state process, many of the concerns regarding long term metallurgical stability resulting from segregation 
during weld solidification are minimized. There may also be other "hybrid" processes that are applicable.

Response: In fiscal year 1996, the Project engaged a panel of weld engineers and Project personnel to evaluate alternative welding techniques and processes. A decision matrix was developed and cold wire automatic GTAW was chosen as the best available technology for Project requirements (CRWMS M\&O 1996 [DIRS 124950]). These conclusions were revisited in fiscal year 2001 by welding engineers and Project personnel, and the same conclusions were reached. The results of the fiscal year 2001 study were documented in the Waste Package Project FY-01 Closure Methods Report (Knapp 2001 [DIRS 156793]).

A number of alternative processes offer shorter weld times and less residual stress due to a smaller heat-effected zone. The problems with close tolerances, catastrophic failures, and the inability to repair errors caused the Project to disqualify these methods. Another factor leading to the adoption of the cold wire automatic GTAW is that it is acceptable to the U.S. Nuclear Regulatory Commission based on years of industry regulation. The Project intends to monitor industry developments of these alternative processes to determine if the negative attributes are resolved. A panel of internationally recognized welding and materials experts is currently reviewing and evaluating the choice of processes, filler material, and all other aspects of the welding and fabrication process.

Industry uses other processes that increase the speed of the GTAW process. The oceanographic pipe-laying industry uses multiple heads that perform within design specifications with higher speeds than necessary for the Project. BSC is considering these other industry processes, but currently does not intend to investigate a backup welding process; rather BSC will allow industry to develop alternative and dependable welding systems and processes that will be evaluated relative to meeting the performance and reliability requirements of the Project.

Comment 3-26 (page 27; see also page 135): Determine the composition effects within the chemical specification for Alloy 22. Composition specifications for Alloy 22 are relatively broad, and the microstructure and properties of Alloy 22 are likely to be sensitive to chemistry and processing history within the specified composition. The goal is to narrow the chemistry ranges so that detrimental phases are kept to a minimum while maintaining satisfactory mechanical properties and corrosion resistance. A set of vacuum melted ingots weighing on the order of 50 pounds could be hot rolled to plate stock, and thus provide a substantial supply of test material. The effects of thermal exposures could then be determined, along with spot checks of the mechanical properties and corrosion behavior. In addition, autogenous GTA weld beads could be made on test coupons and examined before and after thermal exposures to provide information on how to optimize the filler metal chemistry. It would also useful to make several heats of weld wire with modified compositions to check the weldability.

Response: The Project will initiate testing of the variability in the base metal-weld metal composition in early fiscal year 2003 and provide information regarding the mechanical properties of a matrix of approximately 49 combinations, all of which are within the ASME composition ranges. This test is designed to provide weldability, mechanical properties (including impact data), and microstructural information. Sufficient material will be processed to provide other specimens as needed by the corrosion-testing program. These samples will be 